\title{
Linking the ubiquitin-proteasome pathway to chromatin remodeling/modification by nuclear receptors
}

\author{
H K Kinyamu, J Chen and T K Archer \\ Chromatin and Gene Expression Section, Laboratory of Molecular Carcinogenesis, National Institute of Environmental Health Sciences, National Institutes of Health, \\ 111 Alexander Drive, PO Box 12233 (MD E4-06), Research Triangle Park, North Carolina 27709, USA
}

(Requests for offprints should be addressed to T K Archer; Email: archer1@niehs.nih.gov)

\begin{abstract}
Over 25 years ago, eukaryotic cells were shown to contain a highly specific system for the selective degradation of short-lived proteins, this system is known as the ubiquitin-proteasome pathway. In this pathway, proteins are targeted for degradation by covalent modification by a small highly conserved protein named ubiquitin. Ubiquitin-mediated degradation of regulatory proteins plays an important role in numerous cell processes, including cell cycle progression, signal transduction and transcriptional regulation. Recent experiments have shown that the ubiquitin-proteasome pathway is also involved in nuclear hormone receptor (NR)-mediated transcriptional regulation. The idea that the ubiquitinproteasome pathway is involved in NR-mediated transcription is strengthened by experiments showing that ubiquitinproteasome components are recruited to NR target gene promoters. However, it is not clear how these components modulate NR-mediated chromatin remodeling and gene expression. In this review, we postulate the role of the ubiquitin-proteasome pathway on NR-mediated chromatin remodeling and gene regulation based on the current knowledge from studies implicating the pathway in chromatin structure modifications that are applicable to NR function. Since evidence from this laboratory, using the glucocorticoid receptor responsive mouse mammary tumor virus (MMTV) promoter organized as chromatin, suggest that the ubiquitin-proteasome system may be involved in the elongation phase of transcription, we particularly concentrate on chromatin modifications associated with the elongation phase.
\end{abstract}

Journal of Molecular Endocrinology (2005) 34, 281-297

\section{Introduction}

\section{Overview of the ubiquitin-proteasome pathway}

Proteins exist in a dynamic state in the cell, with multiple pathways leading to their degradation (Glickman \& Giechanover 2002). The best-described pathway is the ubiquitin-proteasome system which degrades the bulk of cellular proteins in an energy-dependent manner (Ciechanover et al. 2000, Goldberg et al. 2001, Glickman \& Ciechanover 2002) (Fig. 1). The ubiquitin-proteasome pathway plays a pivotal role in the degradation of shortlived and regulatory proteins important in a variety of cellular processes, including cell cycle progression, modulation of cell surface receptors and ion channels, antigen presentation and more recently nuclear hormone receptors (NRs) (Glickman \& Giechanover 2002, Nawaz \& O'Malley 2004). Degradation of cellular proteins via the ubiquitin-proteasome pathway is a highly complex and tightly regulated process. For this reason, dysregulation of the ubiquitin-proteasome system can potentially affect many cellular processes in health and disease (Schwartz \& Ciechanover 1999, Ciechanover \& Brundin 2003, Ohta \& Fukuda 2004). In this review, we postulate the importance of the ubiquitin-proteasome system in NR-mediated chromatin remodeling and transcriptional regulation.

\section{Ubiquitin activation}

Targeting cellular proteins for degradation via the ubiquitin-proteasome pathway involves two discrete steps (Glickman \& Ciechanover 2002, Pickart 2004). First, the protein substrate is tagged by covalent attachment of multiple ubiquitin molecules to generate the polyubiquitin degradation signal. Second, the tagged protein is degraded by the $26 \mathrm{~S}$ proteasomal complex. The process and the biochemical steps involved in ubiquitination and polyubiquitination have been reviewed in detail elsewhere, but we include a brief description of the system in this review (Glickman \& Ciechanover 2002, Pickart 2004).

Briefly, conjugation of ubiquitin to the protein substrate involves a three-step enzyme cascade. In the first step, the C-terminus of ubiquitin is activated in an ATPdependent step and covalently linked by a thioester bond to an active cysteine site on the ubiquitin-activating 




Figure 1 An overview of the ubiquitin-proteasome system showing enzymatic cascade involved in activation of ubiquitin and subsequent targeting of the protein substrate to the proteasome. The ubiquitin pathway initiates via an ATP-dependent activation of free ubiquitin (Ub) by a ubiquitin-activating enzyme (E1). The activated ubiquitin is transferred to a ubiquitin-conjugating enzyme (E2) and finally to a ubiquitin ligase (E3) which targets the ubiquitin to a lysine residue of a specific protein substrate. The process is repeated to mark the protein substrate (target) with a polyubiquitin chain, a recognition signal (Ub-S) for the 195 and subsequent degradation of the protein by the $20 \mathrm{~S}$ proteasome. Listed are key enzymes in the ubiquitin-proteasome pathway involved in NR-mediated transcriptional regulation (Ciechanover \& Schwartz 1998, Fan et al. 1999, Kang et al. 2002, Reid et al. 2003, Yan et al. 2003, Nawaz \& O’Malley 2004, Perissi et al. 2004).

enzyme (UAG), E1. In the second step, activated ubiquitin is transferred to one of the many ubiquitin carrier/ conjugating enzymes (UBC), E2 enzymes, via another thioester bond. The E2 enzyme then transfers the activated ubiquitin via an isopeptide bond to a lysine residue in the target protein bound to a specific E3 ubiquitin ligase (Fig. 1). Depending on the type of E3 ligase, the transfer of ubiquitin to the substrate is either direct or indirect. In most organisms, including humans and yeast, a single E1 enzyme, activates ubiquitin for an entire array of E2 conjugating enzymes. The human genome project reveals over 40 different potential E2s and over 500 different possible E3s (Wong et al. 2003). The E3 ubiquitin ligases exist in multiple families and ultimately it is the E3s alone or in combination with the E2 that determine the specificity of substrate recognition by the $26 \mathrm{~S}$ proteasome (Glickman \& Ciechanover 2002, Giechanover \& Brundin 2003, Pickart 2004).

Recent studies classify several hundred potential E3 ubiquitin ligases in the human genome into two distinct families based on their structural domains and mechanisms of action. These are the Homologous to the
E6-AP C Terminus (HECT) domain ubiquitin ligases and the Really Interesting New Gene (RING) finger E3 ligases (Glickman \& Ciechanover 2002, Ciechanover \& Brundin 2003). For the HECT domain E3 ligases the E2 first transfers the activated ubiquitin to the E3 to form an E3-ubiquitin bond and subsequently the E3 transfers the ubiquitin to the target substrate. The prototypical HECT domain family member is the E6-AP, a $100 \mathrm{kDa}$ protein required for ubiquitination and rapid degradation of p53 in the presence of the human papilloma virus oncoprotein (Scheffner 1998). E6-AP is also a steroid hormone receptor coactivator, and ablation of the E6-AP gene in mice is associated with hormone resistance (Nawaz et al. 1999, Smith et al. 2002). Another member of this family is the yeast RSP5 or hRPF1, which was shown to enhance hormone-dependent activation by the progesterone (PR) and glucocorticoid receptors (GR) in in vitro experiments (Imhof \& McDonnell 1996). RSP5 also conjugates and leads to ubiquitin-dependent degradation of the large subunit of RNA polymerase II (RNA pol II) (Huibregtse et al. 1997). 
The second group is the RING finger E3 ligases, including the U-box and the plant homeo-domain (PHD) proteins that catalyze a direct transfer of the ubiquitin moiety from E2 to the E3 bound substrate (Aravind \& Koonin 2000, Joazeiro \& Weissman 2000). The RING finger E3 ligases are classified into two distinct groups: single- or multi-subunit complexes. Single- subunit E3s such as murine double minute 2 (Mdm2) and Parkin contain the substrate recognition element and the RING finger on the same polypeptide (Fang et al. 2000). Among the multi-subunit RING finger complexes are the anaphase promoting complex (APG), the von-Hippel Lindauu-Elongins B and $\mathrm{C}(\mathrm{VBC})-\mathrm{Cul} 2$ complex and the Skp1-Cullin/cdc53-F-box (SCF) complex (Peters 1998, Jackson et al. 2000, Tyers \& Jorgensen 2000, Blagosklonny 2001).

Other RING finger proteins shown to mediate ubiquitination in in vitro assays include the product of the breast and ovarian cancer susceptibility gene 1 (BRCAl) (Brzovic et al. 2001). BRCAl decreases estrogen receptor (ER) and increases androgen receptor (AR) transcriptional activity (Fan et al. 1999, Park et al. 2000). The U-box derivatives of the RING finger E3s such as C-terminus of Hsp interacting protein (CHIP), may act as E4 ligases to facilitate polyubiquitination of specific substrates, including NRs (Patterson 2002). Thus, as we shall see, the HECT and RING finger domain family of E3 ligases is critically involved in NR function (Nawaz \& O’Malley 2004).

\section{The 265 proteasome holoenzyme}

The proteasome holoenzyme, also known as the $26 \mathrm{~S}$ proteasome, is the major cytosolic and nuclear protease complex that is responsible for the ATP-dependent proteolytic degradation of cellular proteins (Bochtler et al. 1999, Glickman \& Giechanover 2002). The proteasome is highly conserved in eukaryotic evolution and exists as two major subcomplexes: the 19S regulatory particle and the $20 \mathrm{~S}$ catalytic core particle (CP). The 20S core particle is sandwiched between two 19S regulatory particles (RP), also called PA700 (Fig. 1). Mammalian cells also contain a second regulatory complex, the 11S regulator or PA28, which does not catalyze degradation of proteins but is involved in antigen presentation (Rechsteiner et al. 2000). The 19S particle has two structural subunits: the 'lid' and the 'base'. Initially the proteasome was regarded primarily as a 'cycler' of misfolded proteins, but over the last decade, the function of this multi-enzyme complex has proven to be multifaceted. Individual components of the complete $26 \mathrm{~S}$ proteasome are involved in different tasks as discussed below.

The 195 regulatory particle The $19 \mathrm{~S}$ regulator has ubiquitin hydrolysis activity and serves multiple roles for regulating the activity of the proteasome, including selecting substrates, preparing them for degradation, translocating them into the core particle and dictating the end products generated by the core particle after digestion. Two nomenclatures are used to designate subunits for the lid and the base of the 19S complex. The $\mathrm{S}$ (subunit) or RP (regulatory particle) designate the mammalian and yeast Saccharomyces cerevisiae 19S subcomplex respectively (Dubiel et al. 1995, Finley et al. 1998). Each designation orders the subunits by their molecular mass, but the RP nomenclature also differentiates between Rpt ATPase (Rpt) and nonATPase (Rpn) subunits. The lid has eight non-ATPase subunits - namely S3/Rpn3, Rpn5, S9/Rpn6, S10a/ Rpn7, S11/Rpn9, S12/Rpn8, S13/Rpn11 and S14/ Rpn 12 - and a unique subunit Rpn4/S5b. Degradation of the ubiquitinated substrate requires the lid, suggesting an interaction between the lid and the polyubiquitin chain on the target protein.

The base complex contains the six ATPases S7/Rpt1，S4/Rpt2，S6/Rpt3，S10b/Rpt4，S6/Rpt5/ TBP-1 and S8/Rpt6/SUG1/Tripl - and three non-ATPase subunits S1/Rpn2, S2/Rpn1 and S5a/ Rpn10 (Voges et al. 1999). Each of the six ATPases belongs to the family of ATPases associated with a variety of cellular activities (AAA). The base components of the 19S are critical for recognition of the ubiquitinated substrate by the proteasome.

Several of the 19S subunits are known for their role in processes other than protein degradation. For example, S6/Rpt5/TBP-1, the HIV Tat-binding protein 1, was first defined as a modulator of HIV Tat transactivation (Nelbock et al. 1990, Apcher et al. 2003). The S8/Rpt6/SUG1/Trip1 subunit has been described as a mediator of the TATA-binding protein and a DNA helicase that interacts specifically with transcription factor TFIIH, a component of the RNA polymerase holoenzyme (Weeda et al. 1997). The subunit S5a/ Rpn10 is also similar to the p44 subunit of the basal transcription factor TFIIH (Aravind \& Ponting 1998). Consequently, some of these components are thought to directly regulate RNA pol II activity and enhance NR function (Ferdous et al. 2001, Ishizuka 2001, Gonzalez et al. 2002).

The 20 S catalytic core The 20S proteasome of eukaryotes contains fourteen subunits. Eukaryotic proteasomes may be thought of as a stack of four rings, two $\alpha$ and $\beta$ rings each with seven distinct subunits arranged in a general barrel structure $\alpha 1-7, \beta 1-7, \beta 1-7, \alpha 1-7$. Structural features of the $20 \mathrm{~S}$ core block the random degradation of proteins providing a high level of substrate specificity. The $\alpha$-subunits forming outer rings have no catalytic activity, but play a role in the interaction of the $20 \mathrm{~S}$ and $19 S$ regulatory particle. In eukaryotes, three of the seven $\beta$-subunits have functional proteolytic sites that differ in 
their specificities. These include two sites of each of the following types: chymotrypsin-like activity that cut hydrophobic residues, trypsin-like sites that cleave basic amino acids and caspase-like sites also known as post-glutamyl peptide hydrolase-like (PGPH) sites, that cleave acidic residues. Recently, the development of specific proteasome inhibitors that target specific catalytic sites has proved valuable for research probing the function of the ubiquitin-proteasome pathway in cellular processes (Kisselev \& Goldberg 2001). Proteasome inhibitors, such as the Streptomyces metabolite lactacystin and synthetic compounds such as MG132, have been used extensively to study the effects of the ubiquitin-proteasome pathway on NR function (Lonard et al. 2000, Wallace \& Cidlowski 2001, Deroo et al. 2002).

\section{COP9 signalosome}

Recently a novel protein complex called the COP9 signalosome (CSN) has been identified in eukaryotes (Deng et al. 2000). The CSN complex is highly conserved from plants to mammals (Wei et al. 1994). The eight subunits (CSN1-8) of the CSN share sequence homologies with eight subunits of the lid of the19S regulatory particle of the $26 \mathrm{~S}$ proteasome (Glickman et al. 1998). The CSN is thought to cooperate with the $26 \mathrm{~S}$ proteasome in regulating protein stability (Schwechheimer \& Deng 2001). Due to its control over the ubiquitin-proteasome system, C.SN is implicated in a variety of biological processes also regulated by the $26 \mathrm{~S}$ proteasome. These include, but are not limited to, Drosophila and mammalian development, transcriptional regulation, cell cycle control and cell signaling (Bech-Otschir et al. 2002, Harari-Steinberg \& Chamovitz 2004). Biochemically, the CSN has been implicated in two distinct processes: regulation of protein degradation through deneddylation of the cullin subunit of the RING finger complex, SCF (Skp1/cullin/F-box) E3 ubiquitin ligases; and modulation of kinase signaling pathways (reviewed in Bech-Otschir et al. 2002, Wei \& Deng 2003). In all eukaryotes tested, the CSN acts to scaffold the NEDD8, a small ubiquitin-like protein, from the cullin subunit of the SCF-E3 ubiquitin ligase complex, thereby inactivating the complex (von Arnim 2003, Chiba \& Tanaka 2004). The most conserved of the CSN subunits are CNS2/Alien and CSN5/Jab1. CSN2/ Alien, also known as thyroid hormone receptor (TR) interacting protein (Trip 15) is a co-repressor of NR, TR and vitamin D receptor (VDR) (Lee et al. 1995, Dressel et al. 1999, Altincicek et al. 2000). CSN5/Jabl is a c-Jun activating binding protein that specifically stabilizes c-Jun DNA complexes to activate c-Jun-mediated transcription (Chamovitz \& Segal 2001). Using yeast and mammalian two-hybrid system, CSN5 was shown to interact with both progesterone receptor $(\mathrm{PR})$ and the steroid receptor co-activator $1(\mathrm{SRC}-1)$ to potentiate $\mathrm{PR}$ and other NR-mediated transcriptional activation (Chauchereau et al. 2000). The functional significance and the molecular mechanisms of these interactions are not characterized. Interestingly, CSN subunits are homologous to the $19 \mathrm{~S}$ proteasome and CSN5/Jab1 corresponds to the Rpn11 subunit of the 19S regulatory particle. Whether COP9 signalosome is involved in NR stability/degradation is unknown. However, given the function of COP9 in deneddylation of the SCF-E3 ligase complex, we can speculate a role of CSN5 on NR protein stability. Modification by NEDD8 (neddylation) is required for proteasome-mediated degradation of estrogen receptor alpha (ER $\alpha)$ (Fan et al. 2003). It would be interesting to explore whether the CSN5/Jab1 subunit is involved in deneddylation and neddylation of $\mathrm{ER} \alpha$ as observed for the SCF complex. Other evidence for a role of CSN in NR receptor function, comes from experiments showing that Jab1/CSN5 colocalizes with NEDD8 in murine embryogenesis, a process controlled by a number of NRs, including the estrogen receptor (Carrabino et al. 2004). In the future, it will be critical to determine whether any of the enzymatic activities associated with the signalosome are involved in the control of NR protein stability and transcriptional regulation.

\section{Role of the ubiquitin-proteasome pathway in chromatin structure and gene expression}

\section{Ubiquitin and chromatin structure}

While the function of the ubiquitin system in protein degradation is well established, it is becoming clear that modification by ubiquitin may have additional and distinct roles in biology (Conaway et al. 2000, Ulrich 2002, Lipford \& Deshaies 2003, Muratani \& Tansey 2003). Indeed, there is a growing body of evidence indicating that ubiquitin and proteasomes are intimately involved in chromatin structure modifications and gene control (Zhang 2003, Osley 2004). Within the eukaryotic nuclei, DNA associates with nuclear proteins to form chromatin. The fundamental structural unit of chromatin, the nucleosome, is composed of 146 base pairs of DNA wrapped around an octamer of highly conserved histone proteins $\mathrm{H} 2 \mathrm{~A}, \mathrm{H} 2 \mathrm{~B}, \mathrm{H} 3$ and $\mathrm{H} 4$ (Luger et al. 1997). Organization of the genome into chromatin impedes a number of biological processes, including transcription. As a result, chromatin has to undergo a number of structural modifications for transcription to occur (Wolffe \& Hayes 1999). Recent studies indicate that covalent modifications of histone tails - including acetylation, methylation, phosphorylation, ubiquitination, sumoylation, and poly-ADP-ribosylation - play a vital role in regulating chromatin structure dynamics 
and gene expression (Fischle et al. 2003b, Nathan et al. 2003). Modification of histones by ubiquitin has recently come to the forefront as a previously unrecognized level of transcriptional control (Jason et al. 2002, Ulrich 2002, Muratani \& Tansey 2003, Zhang 2003). The involvement of ubiquitin in chromatin structure was realized over 25 years ago, when histone H2A was identified as the first protein to be ubiquitinated (Goldknopf et al. 1975, Zhang 2003, Pickart 2004). To date the precise role of this modification in regulating chromatin structure and/or function is unknown, although a role of ubiquitinated $\mathrm{H} 2 \mathrm{~A}$ in higher order chromatin folding has been proposed (Jason et al. 2002, Zhang 2003).

In addition to histone $\mathrm{H} 2 \mathrm{~A}$, histone $\mathrm{H} 2 \mathrm{~B}$ is also ubiquitinated in both yeast and humans (Thorne et al. 1987). A number of yeast studies have explored the impact of ubiquitinated histone $\mathrm{H} 2 \mathrm{~B}$ ( $\mathrm{uH} 2 \mathrm{~B}$ ) on chromatin structure and transcriptional regulation (reviewed in Osley 2004). Together with histone H2A and $\mathrm{H} 2 \mathrm{~B}$, histone $\mathrm{H} 3$ and $\mathrm{H} 1$ are also ubiquitinated (Chen et al. 1998, Pham \& Sauer 2000). Specifically, TAFII250, a component of general transcription factor TFIID, exhibits ubiquitin-activating/conjugating (E1/ E2) activity leading to the ubiquitination of the linker histone H1 (Pham \& Sauer 2000). Currently, it is not clear how ubiquitinated histones regulate chromatin structure and function. In the sections that follow, we review the role of these modifications within chromatin and their potential contributions to NR-mediated gene regulation.

\section{Ubiquitin and chromatin structure: implications for NR-mediated gene transcription}

Transcription occurs within the context of chromatin. In higher eukaryotes, histone ubiquitination is a prominent modification that is associated with alteration of nucleosome structure (Fischle et al. 2003b, Nathan et al. 2003). While the role of ubiquitinated histones has not been extensively explored with respect to NR-mediated transcriptional regulation, it is well known that NRs interact with chromatin to regulate gene expression. A number of earlier studies suggest that histone ubiquitination is involved in gene transcription both in a positive and negative manner. For example, ubiquitinated H2A is abundant in actively transcribing regions of the mouse dihydrofolate reductase (DHFR) and hsp70 genes (Barsoum et al. 1982, Levinger \& Varshavsky 1982). In other reports, ubiquitinated histones colocalize with inactive transcriptional regions. Even more interesting with respect to NR function is the fact that ubiquitinated $\mathrm{H} 2 \mathrm{~A}$ is found in transcriptionally inactive compartments such as the sex body of mouse spermatids (Baarends et al. 1999). Other data suggest that ubiquitinated H2A is involved in chromatin rearrangement during spermatogenesis (Baarends et al. 1999).
Rad6/Ubc2 ubiquitinates histone $\mathrm{H} 2 \mathrm{~A}$ in vitro and is implicated in the ubiquitination of H2A in vivo (Baarends et al. 1999, Haas et al. 1991). The mammalian homologs of yeast Rad6/Ubc2, HR6A and HR6B function in mouse spermatogenesis. HR6A expression is decreased during spermatogenesis, but the HR6B is enriched in the testis at the time of histone-protamine transition (Roest et al. 1996). Deletion of HR6B in mice results in male sterility and defects in spermatinogenesis (Roest et al. 1996). In addition, extensive ubiquitination of histone $\mathrm{H} 2 \mathrm{~A}$ is observed in pachytene stage of prophase 1 and in elongating spermatids, while ubiquitination by HR6B is proposed to trigger removal of histones to allow chromatin condensation and packaging in spermatogenesis (Baarends et al. 1999). Intriguingly, ubiquitinated histone $\mathrm{H} 3$ is also found in elongating spermatids (Chen et al. 1998). Since spermatogenesis is a process regulated by androgen and estrogen receptors (members of the NR super family), these observations may imply a role for ubiquitinated histone $\mathrm{H} 2 \mathrm{~A}$ and $\mathrm{H} 3$ in NR function.

Ubiquitinated histone $\mathrm{H} 2 \mathrm{~B}$ is also associated with gene silencing in yeast Saccharomyces cerevisiae. For example, a recent study shows that Rad6 ubiquitinates histone $\mathrm{H} 2 \mathrm{~B}$ and leads to silencing of the ARG1 gene, which encodes argininosuccinate synthetase (Turner et al. 2002). Additional evidence for a role of $\mathrm{uH} 2 \mathrm{~B}$ in gene regulation is provided by studies showing that ubiquitination of histone $\mathrm{H} 2 \mathrm{~B}$ is associated with methylation of histone $\mathrm{H} 3$ at specific lysine residues, an activity that regulates transcription both in a positive and negative manner (Briggs et al. 2002, Dover et al. 2002, Sun \& Allis 2002, Henry et al. 2003, Hwang et al. 2003, Wood et al. 2003). The regulated interplay between ubiquitination of histone $\mathrm{H} 2 \mathrm{~B}$ and methylation of histone $\mathrm{H} 3$ indicates that histone ubiquitination is an integral part of the 'histone code' used by cells to distinguish between transcriptionally active and inactive chromatin (Fischle et al. 2003a). Such studies can be relevant to NR, as interaction between various histone modifications has been demonstrated to play a role in NR function (Ma et al. 2001, Li et al. 2002, 2003).

\section{The role of $26 \mathrm{~S}$ proteasome holoenzyme components in chromatin modification and transcription}

While there is ample evidence that ubiquitination and ubiquitin enzymes can influence some aspects of chromatin structure and transcription, there remains a question as to whether the 26S holoenzyme components are involved in these processes (Conaway et al. 2000, Muratani \& Tansey 2003). Recent evidence suggests that the 19S components are directly involved in 
transcription in yeast systems. Analysis of DNA using chromatin immunoprecipitation assays shows that 19S proteasome components occupy the GAL1-10 promoter (Gonzalez et al. 2002). RNA pol II transcription may be viewed as involving four steps: the formation of the pre-initiation complex (PIG), followed by initiation, elongation and termination of transcription (Roeder 1996). Genetic experiments in which yeast strains lacking alleles of SUG1/Rpt6 and SUG2/Rpt4 exhibit elongation defects suggest that SUG1/Rpt6 is directly involved in transcriptional elongation in yeast (Ferdous et al. 2001, 2002, Sun et al. 2002). In these experiments the role of $19 \mathrm{~S}$ complex in transcriptional elongation is further supported by the observation that SUG1/Rpt6 physically interacts with the elongation factor Gdc68, a component of the facilitates chromatin transcription (FACT) complex (LeRoy et al. 2000, Ferdous et al. 2001).

Further support for a role of the 26S proteasome in transcription comes from a recent report demonstrating that the $20 \mathrm{~S}$ proteasome physically interacts with RNA pol II and is recruited to the sites of active transcription on the GAL1 and HSP82 promoters of yeast (Gillette et al. 2004). This supports the idea that the 19S AAA proteins independent of 20S (APIS) complex is required early in the transcription process and at the start of elongation while the $20 \mathrm{~S}$ is exclusively recruited to the coding region of the gene and is involved in clearing the stalled RNA pol II and regulating the termination step (Gillette et al. 2004).

Phosphorylation of the carboxy-terminal domain (CTD) of the largest subunit of pol II is known to switch the RNA pol II from the initiation to the elongation phase of transcription (Komarnitsky et al. 2000, Ahn et al. 2004). Phosphorylation of the CTD then signals ubiquitination of the large subunit of RNA pol II, allowing the elongating polymerase to recruit a diverse collection of elongation factors (Mitsui \& Sharp 1999, Shilatifard et al. 2003). Studies in yeast Saccharomyces cerevisiae and Drosophila melanogaster have demonstrated that recruitment of elongation factors by the elongating RNA pol II is linked to specific chromatin modifications (Gerber \& Shilatifard 2003, Hampsey \& Reinberg 2003). In Drosophila melanogaster the transcriptionally active/ elongating form of RNA pol II phosphorylated at serine 2 colocalizes with histone $\mathrm{H} 3$ methylated at lysine 4 and 79 , suggesting that these modifications are associated with transcriptionally active chromatin (Gerber \& Shilatifard 2003). Additionally, in yeast, ubiquitination of histone H2B directs methylation of histone $\mathrm{H} 3$ at lysine 4 and 79, modifications associated with active chromatin (reviewed in Osley 2004). More precisely, recent evidence links $19 \mathrm{~S}$ proteasomal ATPase components to ubiquitination of histone $\mathrm{H} 2 \mathrm{~B}$ and methylation of histone $\mathrm{H} 3$ lysine 4 and 79, and indeed directly ties the $26 \mathrm{~S}$ proteasome components to specific chromatin modification and transcription (Ezhkova \& Tansey 2004).

\section{The link between the ubiquitin-proteasome pathway and NR-mediated transcriptional regulation}

Thus far, the body of evidence suggests that posttranslational modification by ubiquitin is directly tied to specific chromatin structure modifications independent of proteolysis. The question remains whether these chromatin modifications or proteolysis via the ubiquitinproteasome pathway is involved in transcriptional regulation with respect to NRs. Eukaryotic transcription is a complex process tightly regulated by the activity of the RNA pol II enzyme (Roeder 1996). The activity of the large subunit of RNA pol II is, at least in part, regulated by the ubiquitin-proteasome pathway, demonstrating a direct link between ubiquitin-mediated proteolysis and transcription (Bregman et al. 1996, Huibregtse et al. 1997). The HECT domain E3 ubiquitin ligase Rsp5, which is also a steroid hormone receptor coactivator, has been shown to ubiquitinate and target RNA pol II to the proteasome during DNA damage (Imhof \& McDonnell 1996, Beaudenon et al. 1999).

The levels of transcription factors that act in conjunction with RNA pol II to effectively synthesize mRNA are critical to transcriptional regulation. Consequently, the levels and activities of transcriptional activators and repressors are tightly controlled. Accumulating evidence indicates that ubiquitin plays an important role in transcriptional regulation through proteasome-dependent and -independent degradation of transcriptional activators (Conaway et al. 2000, Muratani \& Tansey 2003). The ubiquitin-proteasome pathway tightly regulates a large number of key transcriptional regulators including p53, c-Fos, c-Jun and more recently NRs and their cofactors (Salvat et al. 1999, Nawaz \& O'Malley 2004).

NRs are one of the largest groups of transcription factors, with more than 49 distinct members now identified in the human genome (Maglich et al. 2001, Robinson-Rechavi et al. 2001, Evans \& O’Malley 2004 (www.nursa.org)). NR-mediated transcriptional regulation is controlled by multiple factors. The classical mode of action of NRs involves binding of a small lipophilic ligand to the receptor and the interaction of the receptor-ligand complex with hormone response elements embedded within chromatin in target gene promoters, followed by recruitment of basal transcription machinery and activation/repression of transcription (Mangelsdorf et al. 1995). This cascade of events is facilitated by numerous factors that include chromatin remodeling factors, coactivators and corepressors (Collingwood et al. 1999, Kinyamu \& Archer 2004, Privalsky 2004). Consequently, NR-mediated transcriptional regulation is subject to multiple levels of control, including changes in 
chromatin structure within gene promoters and regulation of receptor and cofactor levels by the ubiquitinproteasome pathway (Kinyamu \& Archer 2004, Nawaz \& O'Malley 2004). The transcriptional signal induced by an activated NR is highly dependent on receptor and cofactor protein levels. Subsequently, any changes in receptor levels would affect gene expression. Studies showing that several members of the NR super family - including the glucocorticoid (GR), estrogen (ER), progesterone (PR), androgen (AR), thyroid (TR), retinoic acid (RAR) and vitamin $\mathrm{D}(\mathrm{VDR})$ receptors - undergo ligand-dependent proteasome-mediated proteolysis provide a direct link between NR-mediated gene transcription and the ubiquitin-proteasome pathway (reviewed in Nawaz \& O’Malley 2004).

Rapid degradation of a number of key transcriptional regulators, such as p53, by the ubiquitin-proteasome is correlated to their phosphorylation state (Meek 1999). Phosphorylation is thought to signal substrate recognition by the enzymes in the ubiquitination pathway. Similarly, the phosphorylation state of NRs plays a pivotal role in the ligand-mediated stability of these receptors. The GR upon ligand binding is hyperphosphorylated and degraded via the ubiquitinproteasome pathway (Webster et al. 1997, Wallace \& Cidlowski 2001, Ismaili \& Garabedian 2004). Phosphorylation of the PR by mitogen-activated protein kinase (MAPK) leads to ligand-dependent degradation of the receptor (Lange et al. 2000). Phosphorylation of the retinoic acid receptor $\gamma 2$, $(\operatorname{RAR} \gamma 2)$ by p38 MAPK signals its ligand-dependent degradation (Gianni et al. 2002). Furthermore, the phosphorylation state of RARs dictates differential regulation between $\operatorname{RAR} \gamma 2$ and RAR $\alpha$ by the ubiquitin-proteasome pathway (Kopf et al. 2000). Specifically, upon phosphorylation, RAR $\gamma 2$ undergoes RA-mediated degradation, while the phosphorylated RAR $\alpha$ is stabilized. Finally, the peroxisome proliferator-activated receptor alpha (PPAR $\alpha)$ is also stabilized by phosphorylation in the presence and absence of its ligand (Blanquart et al. 2004).

A direct role of the ubiquitin-dependent proteolysis in transcriptional regulation is suggested by recent reports showing an overlap between transcription activation domains and sequences within transcriptional activators that specify protein turnover (Salghetti et al. 2001, Muratani \& Tansey 2003). Interestingly, the PEST (Pro $(\mathrm{P})$, Glu (E), Ser (S) and Thr (T)) motifs within transcriptional activators that contain recognition sites for ubiquitination, referred to as 'degrons' are also sequences targeted for phosphorylation (Salghetti et al. 2000). Intriguingly, receptor phosphorylation and degradation is coupled to receptor-mediated transactivation. Indeed, for the GR, mutation of the PEST sequence within the site of phosphorylation inhibits GR degradation and consequently GR-mediated transcriptional activity (Wallace \& Cidlowski 2001). Phos- phorylation of the PR by MAPK couples PR-mediated transcriptional activity to ligand-dependent degradation (Shen et al. 2001). Likewise phosphorylation of the AF-1 domain of the retinoic acid receptor, RAR $\gamma 2$ by $\mathrm{p} 38$ MAPK and recruitment of SUG1 a 19S regulatory subunit to AF-2 domain signals RA-dependent degradation and transactivation of RAR $\gamma 2$ receptor (Gianni et al. 2002). Conversely, phosphorylation of PPAR $\alpha$ stabilizes the receptor and induces PPAR $\alpha$ transcriptional activity (Blanquart 2004). Thus, the transcriptional potency NRs is correlated with their protein degradation as shown for other transcriptional activators (Molinari et al. 1999, Salghetti et al. 2001).

Additional factors can influence ligand-dependent degradation of NRs. A recent study provides evidence that specific cofactors can facilitate ligand-dependent degradation of the ER. The p160 coactivator AIB1 uniquely mediates agonist-dependent, but not antagonistdependent, ER $\alpha$ protein degradation via the ubiquitinproteasome pathway (Shao et al. 2004). While the effect of AIB1 on ER $\alpha$ stability is independent of the E3 ligase E6-AP, AIB 1 may modulate ER $\alpha$ degradation via posttranslational modifications including, but not limited to, phosphorylation of the receptor (Shao et al. 2004). Of note, is that AIBl-mediated ligand-dependent degradation of ER $\alpha$ is correlated with recruitment of transcriptional machinery, including RNA pol II, to ER-target promoter, again tying ubiquitin-proteasome proteolysis of the receptor to transcriptional regulation.

Recent reports suggest cross-signaling between receptors as another means of modulating ligand-dependent degradation of NR via the ubiquitin-proteasome pathway. For example, ER mediates a decrease in GR levels in the presence of estradiol, while hypoxic conditions and 2,3,7,8-tetrachlorodibenzo-p-dioxin (TCDD)-activated aryl hydrocarbon receptor target the ER for degradation (Stoner et al. 2002, Kinyamu \& Archer 2003, Wormke et al. 2003). Such negative crosstalk is sometimes mediated by the receptor interacting with ubiquitin-proteasome enzymes. In the case of the GR, estradiol increases protein expression of Mdm2, which physically interacts and targets the GR to the proteasome (Sengupta \& Wasylyk 2001, Kinyamu \& Archer 2003).

NR-mediated transcriptional regulation is a highly complex process involving multiple coregulatory factors. NR coregulators were first discovered as proteins that enhance NR-mediated transcriptional activation (McKenna \& O’Malley 2002). Subsequently, coactivators were shown to contain enzymatic activities such as histone acetyltransferase (HAT), histone methyltransferase (HMT) and ATPase activities (Collingwood et al. 1999, Kinyamu \& Archer 2004, McKenna \& O’Malley 2002).

Similar to the receptors, the turnover of NR cofactors is tightly regulated by the proteasome (Zhang et al. 1998, 
Lonard et al. 2000, 2004, Yan et al. 2003). Degradation of specific coregulators by the proteasome is ligand specific. For example, 17B-estradiol, but not 4-hydroxytamoxifen or raloxifene decrease SRG-1 and SRC-3 protein stability (Lonard et al. 2004). Cofactor stability can be modulated by post-translational modifications. Phosphorylation of glucocorticoid receptor interacting protein 1 (GRIP1) by cAMP-dependent protein kinase (PKA) induces its degradation via the ubiquitin-proteasome pathway (Hoang et al. 2004).

The recognition that a number of enzymes in the ubiquitin-proteasome pathway are also NR cofactors provides another link between the ubiquitin-proteasome pathway and NR function. These include RSP5/RPF1, E6-AP, UBC9 and more recently Mdm2 (Imhof \& McDonnell 1996, Nawaz et al. 1999, Poukka et al. 1999, Saji et al. 2001). The E3 ligase RSP5/RPF1 and E6-AP belong to the HECT domain family and the MDM2 E3 ligase belongs to RING domain family (Glickman \& Ciechanover 2002). A mutation of the HECT domain does not affect the coactivator function of E6-AP, suggesting that the coactivator function is independent of the ligase activity (Nawaz et al. 1999). Additionally, components of the $19 \mathrm{~S}$ regulatory particle SUG1/ Trip1/Rpt6 and TBP-1/Rpt5 regulate NR transcriptional activity (reviewed in (Nawaz \& O'Malley 2004). Other evidence shows that ubiquitin-like molecules, including small ubiquitin-like modifier 1 (SUMO-1) and NEDD8 may also regulate NR function (Poukka et al. 2000, Fan et al. 2003). In this regard, the ubiquitinproteasome components act as cofactors and function to activate or repress NR transcription.

The ubiquitin-proteasome components involved in NR-mediated transactivation represent different steps of the ubiquitin-proteasome pathway and different enzymatic activities, including ubiquitin conjugation, ubiquitin ligase and ATPase activities (Fig. 1) (Imhof \& McDonnell 1996, Fraser et al. 1997, Nawaz et al. 1999, Poukka et al. 1999, Dennis et al. 2001). The complexity of the system is increased by the finding that specific ubiquitin-proteasome enzymes target specific receptors and coregulators (Yan et al. 2003, Perissi et al. 2004). The E3 ligase $\mathrm{Mdm} 2$ targets the $\mathrm{GR}$ and $\mathrm{AR}$ to the proteasome and is implicated in ER-dependent degradation of the GR (Sengupta \& Wasylyk 2001, Lin et al. 2002, Kinyamu \& Archer 2003). The G-terminal Hsp-interacting protein (CHIP) an E3/E4 ubiquitin ligase stimulates GR and AR degradation (Connell et al. 2001, Cardozo et al. 2003). Of particular significance is the recent report showing that transducin- $\beta$-like (TBL1) and TBL1-related protein (TBLR1), two subunits of the nuclear receptor-corepressor (NCoR) and silencing mediator for retinoic acid receptor and thyroid hormone receptor (SMRT) co-repressor complexes, contain an F-box motif similar to that of the SCF-E3 ligase complex that mediates degradation of the NCoR on NR gene promoters allowing transcription to proceed (Perissi et al. 2004). The study also demonstrates a distinct requirement of ubiquitin enzymes in NR function in vivo. Disruption of the TBL1 gene in embryonic stem cells decreases PPAR $\gamma$-induced adipogenic differentiation, indicating a biological function for TBL1 in NRmediated gene activation events (Perissi et al. 2004).

The requirement for the ubiquitin-proteasome components in NR-mediated transcription was first suggested by studies using proteasome inhibitors (Nawaz et al. 1999, Lonard et al. 2000). Treatment of mammalian cells with 26S proteasome inhibitors inhibits ER-, ARand PR-mediated gene activation, but increases GR levels and facilitates GR-mediated transactivation (Nawaz et al. 1999, Wallace \& Cidlowski 2001, Deroo et al. 2002). This suggests a differential effect of proteasome inhibitors among receptors, which is quite surprising since the effect of proteasome inhibitors on the mobility of the ER and GR within the nuclear matrix is similar (Stenoien et al. 2001, Deroo et al. 2002, Reid et al. 2003, Schaaf \& Cidlowski 2003). This may be explained by the fact that ubiquitin-proteasome components show some specificity with regard to NR-mediated transcription. The E2 enzyme Ubc2 and E3 ligase E6-AP are necessary for TR transcriptional activation (Perissi et al. 2004). SUG1/Tripl an ATPase component of the $19 \mathrm{~S}$ regulatory particle promotes ubiquitination and degradation of $\mathrm{ER} \alpha$ and $\mathrm{ER} \beta$, thereby suppressing their transcriptional activity (Masuyama \& Hiramatsu 2003). In contrast to the effect on $\mathrm{ER} \alpha$ and $\mathrm{ER} \beta$, SUG1 has a stimulatory effect on TR transcriptional activity (Fraser et al. 1997). These studies implicate different components of the ubiquitinproteasome system in NR protein stability and transcriptional activation and suggest that specificity of various components involved permit different receptors to adopt varying functional regulatory mechanisms within the cell. For example, Mdm2 increases ER transcriptional activity, but is also associated with a decrease in GR-mediated transactivation (Saji et al. 2001, Sengupta \& Wasylyk 2001, Kinyamu \& Archer 2003, Reid et al. 2003).

Transcriptional activation/repression involves alteration of chromatin structure within promoters of target genes. Together with the activated receptors, coregulators and RNA pol II, proteasome components are also recruited to NR target gene promoters, suggesting their involvement with chromatin. The SUG1/Rpt6/hTripl ATPase, a component of the 19S base particle, is required for efficient transcription by human RNA pol II and binds directly to activation domains of Gal4 and the viral activator VP16 (Swaffield et al. 1995, Chang et al. 2001, Ferdous et al. 2002). Similarly, ubiquitinproteasome components are recruited to natural NR promoters, as exemplified by the occupancy of the E3 ubiquitin ligases (Mdm2, E6-AP) together with the 19S 
base component SUG1/Trip1/Rpt6 to the ER responsive pS2 promoter using chromatin immunoprecipitation assays (Reid et al. 2003, Perissi et al. 2004). The S1/Rpn2/p112, a component of the 19S, occupies the AR responsive prostate specific antigen (PSA) promoter (Kang et al. 2002). TAFII250, a component of the basal transcriptional machinery and a ubiquitin activating/ conjugating enzyme, is part of the initiation complex on NR target promoters (Collingwood et al. 1999).

Although ubiquitin-proteasome components are well represented on NR-regulated target gene promoters, their function in NR-dependent transcription is not well understood. One hypothesis is that the ubiquitinproteasome system directs the turnover of chromatin bound receptors and corresponding cofactors, allowing for attenuation of the transcriptional signal and the promoter to continuously reload transcription factors to ensure further cycles of transcription (Kang et al. 2002, Metivier et al. 2003, Stavreva et al. 2004). It is important to note that alternative mechanisms could explain the effects of proteasome-mediated proteolysis on NR-mediated transcription.

\section{Ubiquitin-proteasome and NR-dependent chromatin remodeling: MMTV as a classic system}

The organization of chromatin is of fundamental significance in transcriptional control by NRs (reviewed in Collingwood et al. 1999, McKenna \& O’Malley 2002, Kinyamu \& Archer 2004, Privalsky 2004). Transcriptional activation by NRs involves alteration of chromatin structure by ATP-dependent chromatin remodeling enzymes in conjunction with histone- modifying machines (McKenna \& O'Malley 2002, Narlikar et al. 2002, Kinyamu \& Archer 2004). The effect of NR-mediated transcription on chromatin structure is determined by changes in accessibility of nucleosomal DNA within target promoters, facilitated by the SWI/SNF, an ATP-dependent chromatin remodelling complex and post-translational modifications of histones such as acetylation, phosphorylation, methylation and ubiquitination (Collingwood et al. 1999, Fischle et al. 2003b, Nathan et al. 2003). In as much as the ubiquitin-proteasome components can modify chromatin directly, they represent a critical regulatory consideration in NR-mediated transactivation. For example, ER recruits the E3 ligases, E6-AP and Mdm2, and the $19 \mathrm{~S}$ proteasome component to the pS2 promoter concomitantly with other factors that have both HAT and HMT activity and have the ability to modify chromatin via histone modifications (Reid et al. 2003, Perissi et al. 2004).

Despite the presence of the ubiquitin-proteasome components on NR target gene promoters, work from our laboratory excludes nucleosomal DNA accessibility as a means of altering chromatin structure by these molecules (Deroo et al. 2002). Transcriptional regulation by the GR is concomitant with chromatin remodeling exemplified by restriction enzyme hypersensitivity on the MMTV promoter (reviewed in Deroo \& Archer 2001, Hsiao et al. 2002, Hebbar \& Archer 2003). Proteasome inhibitors increase GR transactivation of the MMTV promoter in the absence of increased chromatin remodeling as measured by restriction enzyme hypersensitivity (Deroo et al. 2002). This observation suggests that the increased transcriptional ability of the GR in the presence of proteasome inhibitors is downstream of chromatin remodeling normally associated with GR recruiting the SWI/SNF complex to the MMTV promoter (Fryer \& Archer 1998, Fletcher et al. 2002). This idea is supported by the finding that proteasome inhibitors potentiate GR transcriptional activity of transient templates not organized as chromatin (Wallace \& Cidlowski 2001, Deroo et al. 2002,). This suggests that the ubiquitin-proteasome system components are involved in a step downstream of transcriptional initiation including, but not limited to, the elongation step of transcription. Support for this concept comes from experiments showing that ensuing rounds of transcription and recycling of the ER are dependent on the release of the receptor from the promoter, which is dependent on a functional proteasome and requires phosphorylation of the G-terminal domain of RNA pol II, a requirement for transcriptional elongation (Shang et al. 2000, Reid et al. 2003). Studies in Saccharomyces cerevisiae and Drosophila melanogaster suggest that the ubiquitin-proteasome pathway is directly tied to transcription such that direct and specific chromatin modification by ubiquitin may regulate transcriptional elongation (reviewed in Conaway et al. 2000, Muratani \& Tansey 2003, Zhang 2003). If the ubiquitinproteasome system is linked to the elongation step of transcription, then it may explain how proteasome inhibitors would increase GR transcriptional activity. In the section that follows we will examine how the events orchestrated by the ubiquitin-proteasome system may target the elongation step of transcription within NR gene regulation (Deroo et al. 2002, Reid et al. 2003, Archer \& Kinyamu 2004).

\section{A role of chromatin structure modifications associated with the elongating RNA pol II in NR-mediated gene transcription: what can we explore in the future?}

Phosphorylation of the CTD of the largest subunit of pol II is known to switch the RNA pol II from the initiation to the elongation phase of transcription (Komarnitsky et al. 2000, Ahn et al. 2004). Phosphorylation of CTD 
then signals ubiquitination of the large subunit of RNA pol II, allowing the elongating polymerase to recruit a diverse collection of elongation factors (Mitsui \& Sharp 1999, Shilatifard et al. 2003). Studies in yeast Saccharomyces cerevisiae and Drosophila melanogaster have demonstrated that recruitment of elongation factors by the elongating RNA pol II is associated with specific chromatin modifications (Gerber \& Shilatifard 2003, Hampsey \& Reinberg 2003). In Drosophila melanogaster the transcriptionally active/elongating form of RNA pol II phosphorylated at serine 2 colocalizes with histone $\mathrm{H} 3$ methylated at lysine 4 and 79, suggesting that these modifications are associated with transcriptionally active chromatin (Gerber \& Shilatifard 2003). Additionally, in Saccharomyces cerevisiae ubiquitination of histone H2B directs methylation of histone $\mathrm{H} 3$ at $\mathrm{K} 4$ and $\mathrm{K} 79$, modifications associated with active chromatin (reviewed in Osley 2004). Recent evidence links 19S proteasomal ATPase components to ubiquitination of histone H2B and methylation of histone $\mathrm{H} 3-\mathrm{K} 4$ and $\mathrm{K} 79$, and indeed directly ties the $26 \mathrm{~S}$ proteasome components to specific chromatin modification and transcription (Ezhkova \& Tansey 2004).

To date no published studies have addressed whether the ubiquitin-proteasome system is associated with the elongating RNA pol II and histone H3 lysine modification with respect to NRs. Most studies have shown that arginine methyltransferases are NR coactivators, but a role in lysine methylation is not well documented (Kouzarides 2002, Stallcup et al. 2003). Methylation of histone H3-K9 is associated with transcriptional repression by steroid hormone receptors (Ma et al. 2001, Li et al. 2002, 2003). Two recent studies provide evidence that methylation of histone $\mathrm{H} 3$ lysine 4 plays a role in transcriptional regulation by the androgen and ecdysone receptors, members of the NR super family (Kim et al. 2003, Sedkov et al. 2003). Interestingly, on the AR-regulated PSA promoter, the tri-methylated histone $\mathrm{H} 3-\mathrm{K} 4$ is decreased in the promoter region and increased in the coding region in the presence of $\mathrm{AR}$ agonist (Kim et al. 2003). If methylation of $\mathrm{H} 3-\mathrm{K} 4$ is linked to the ubiquitin-proteasome system, this finding supports the observation that proteasome inhibitors silence the PSA promoter (Kang et al. 2002). On the other hand, the direct relationship of histone modification on transcription in higher eukaryotes relative to what is known in yeast is controversial. For example, one study shows histone H3 lysine methylation patterns in higher eukaryotes similar to those in yeast, while another study does not (Liang et al. 2004, Schneider et al. 2004).

What other potential chromatin histone modifications can be orchestrated by the ubiquitin-proteasome components on the NR-regulated genome? The presence of ubiquitinated histones on NR target gene promoters has not been demonstrated to date. However, histone H2A ubiquitination is implicated in sper- matogenesis, a process driven by steroid hormone receptors (Roest et al. 1996, 2004). The E3 ubiquitin ligases, such as Mdm2 and E6-AP, are recruited to NR target gene promoters (Reid et al. 2003). There is also evidence suggesting that $\mathrm{Mdm} 2$ can ubiquitinate histone H2B in vitro and in vivo (Minsky \& Oren 2003). On the occupied promoter, Mdm2 may function like yeast Brel, providing a means to alter chromatin structure within the occupied promoter (Wood et al. 2003). Future studies can evaluate whether histone ubiquitination plays a role in NR-mediated changes in chromatin structure.

Evidence from this and other laboratories suggests that the ubiquitin-proteasome system is involved in GR-mediated transcriptional elongation (Deroo et al. 2002, Reid et al. 2003). There is a potential to utilize the MMTV promoter, organized as chromatin, to explore chromatin modifications associated with the transition from the initiation to the elongation phase of transcription. On the MMTV promoter the elongating polymerase was shown to have a capacity to decondense chromatin, an aspect attributed both to the mechanical effect of the RNA polymerase on the DNA or the ability of the RNA polymerase to associate with a factor or factors that decondense chromatin (Muller et al. 2001).

Changes in histone modifications may provide the platform for association with other factors that can alter chromatin structure (Krogan et al. 2003, Ng et al. 2003, Xiao et al. 2003). In yeast the ATPase of the chromatin remodeling complex ISWI/hSNF2H was shown to recognize chromatin marked by di- and trimethyl histone $\mathrm{H} 3-\mathrm{K} 4$ and to associate with the elongating RNA pol II (Morillon et al. 2003, Santos-Rosa et al. 2003). On the pS2 promoter, the phosphorylated RNA pol II occupies the promoter concomitantly with the elongation factors (Elp1 and 3) and the SWI/SNF complex, although it is not clear whether this association correlates with nucleosomal DNA accessibility (Metivier et al. 2003). Other evidence supporting a role of chromatin remodeling and modifying machines in the elongation step comes from the observation that the $\mathrm{SWI}$ SNF complex is recruited to the coding region of hsp70 promoter (Corey et al. 2003). The elongating polymerase/phosphorylated RNA pol II can recruit putative elongation factors with chromatin remodeling activities such as FACT, although FACT complex occupancy on NR target promoters has not been demonstrated (Orphanides et al. 1999, Mason \& Struhl 2003, Saunders et al. 2003). Conversely, it is known that the FACT complex associates with chromatin remodeling complexes found in the VDR complex WINAC, which also contains SWI/SNF and is required for NR function (Kitagawa et al. 2003).

Additional chromatin modifications that can arise from components of the ubiquitin-proteasome system 


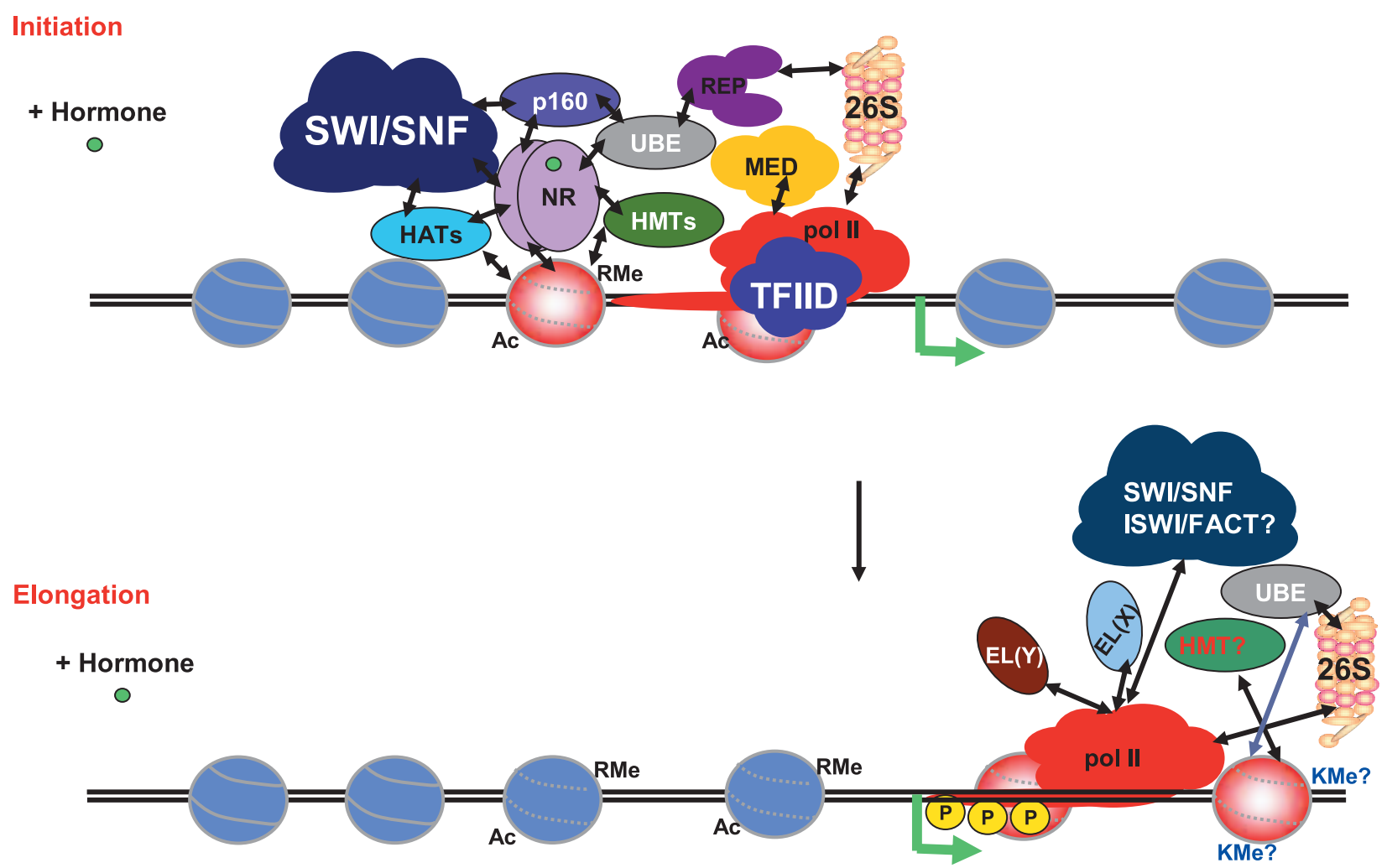

Figure 2 Model for the role of the ubiquitin-proteasome system in NR-mediated chromatin structure modification and transcriptional regulation. In the presence of hormone, NRs bind to hormone response elements embedded within chromatin. The activated NR recruits various groups of chromatin-modifying machines (SWI/SNF, HATs, p160 and HMTs) to remodel chromatin followed by recruitment of the mediator complex (MED) and the general transcriptional machinery (TFIID) allowing transcriptional initiation by RNA pol II. There is a distinct requirement for the ubiquitin enzymes (UBE) and the 26S proteasome (26S) in NR-mediated transcriptional regulation at least via the traditional role in proteolysis of NR and NR co-activators ( $p 160$ ) and co-repressor complexes (REP). (The arrows indicate dynamic interactions between various factors as opposed to a static model (Hager et al. 2004, Stavreva et al. 2004). Based on studies in yeast Saccharomyces cerevisiae, the ubiquitin-proteasome system (UBE, 26S) appears to function at the elongation step of transcription. In NR-mediated transcriptional regulation, we propose that ubiquitin-proteasome components might play a part in switching the RNA pol II from a hypo-phosphorylated to a hyper-phosphorylated state. The elongation phase of transcription is regulated by phosphorylation of the C-terminal domain (CTD) of RNA pol II. The phophorylated RNA pol II may then recruit various factors that modify chromatin (SWI/SNF, ISWI, FACT and $\mathrm{HMT})$ and gene-specific elongation factors (EL(X) or $\mathrm{EL}(\mathrm{Y})$ allowing differential gene regulation by NRs. Kme, methylated histone lysine residue; Rme, methylated histone arginine residue; $\mathrm{AC}$, acetylated histone lysine residue.

may involve modifications in higher-order chromatin structure and/or NR function. TAFII 250, which is a component of the basal transcriptional machinery and a coactivator of NR, is a ubiquitin-activating/-conjugating enzyme that ubiquitinates the linker histone H1. Histone H1 has clear effects on higher-order chromatin structure and phosphorylation of histone $\mathrm{Hl}$ is a critical component of GR-mediated MMTV activation (Bhattacharjee et al. 2001, Georgel et al. 2003). During GR-mediated chromatin remodeling, histone $\mathrm{H} 1$ is lost from the MMTV promoter (Bresnick et al. 1992; reviewed in Deroo \& Archer 2001, Hebbar \& Archer 2003, Kinyamu \& Archer 2004). Upon prolonged glucocorticoid exposure, the following prolonged exposure to hormone is accompanied by dephosphorylation of the global and promoter-associated histone $\mathrm{H} 1$ that is mimicked by kinase inhibitors (Lee \& Archer 1998, Bhattacharjee et al. 2001). Glucocorticoid withdrawal results in a competent promoter and rephosphorylation of histone H1. In addition, recent studies using electrospray mass spectrometry demonstrate that prolonged glucocorticoid treatment leads to dephosphorylation of specific histone $\mathrm{H} 1$ isoforms in mouse cells (Banks et al. 2001). While in vivo data as to the effects of linker histone $\mathrm{Hl}$ in NR-mediated gene regulation are still lacking, linker histones are essential for mouse development and play a role in spermatogenesis, biological processes known to be regulated by NRs (Fan \& Skoultchi 2003, Lin Q. et al. 2004). In particular, inactivation of three mouse histone $\mathrm{Hl}$ isoforms $(\mathrm{H} 1 \cdot 2$, 
$\mathrm{H} 1 \cdot 3$ and $\mathrm{H} 1 \cdot 4$ ) leads to embryonic death at midgestation (Fan \& Skoultchi 2003).

Recent studies show that histone-modifying machines involved in NR function have ubiquitin ligase activity targeted at other proteins. The histone acetyltransferase p300 is a ubiquitin ligase for p53 (Grossman et al. 2003). Histone deacetylase 6 (HDAC6) was shown to interact directly with ubiquitin (Hook et al. 2002, Kawaguchi et al. 2003). The ubiquitin binding of HDAC6 has recently been linked to chromatin compaction in mouse oocytes and fertilized egg (Verdel 2003). Thus, proteins normally recruited to NR target promoters may function as ubiquitin-proteasome components apart from their normal function as a HAT or HDAC, respectively.

The above studies provide a rationale for further exploring chromatin modifications associated with the ubiquitin-proteasome pathway with regard to NR regulation of the elongation phase of transcription.

\section{Conclusion and future prospects: what lays ahead?}

Substantial and elegant observations over the past 5 years support the notion that the ubiquitin-proteasome system plays a role in NR-mediated transcriptional regulation. Most of the evidence suggests that the system contributes to transcriptional regulation via receptor/ cofactor turnover thereby enabling recycling and reutilization of receptor/cofactor complexes to increase transcriptional efficiency (reviewed in Nawaz \& O'Malley 2004). However, proteasome-mediated receptor/cofactor turnover may not be the only mechanism by which the proteasome modulates NR-mediated transcription. For example, as discussed earlier, inhibiting the proteasome increases GRmediated transcriptional activity from the MMTV promoter, an effect presumed to be due to an increase in GR levels in the cell (Wallace \& Cidlowski 2001, Deroo et al. 2002). However, inhibiting the proteasome increases MMTV transcription independent of an increase in GR protein levels (Stavreva et al. 2004). Conversely, for the ER, partial agonists such as trans-hydroxytamoxifen - which stabilize ERs and do not lead to ER degradation - support ER-mediated gene expression independent of proteolysis of the receptor (Wijayaratne 2001, Frasor 2004). These findings support the idea that the ubiquitin-proteasome system is involved in NR gene transcription by other mechanisms apart from receptor turnover. In pursuance of this idea, it will be exciting to explore the possibility that the effects of the ubiquitin-proteasome pathway on NR-mediated gene regulation may be gene specific and dependent on chromatin structure/architecture of the target promoters rather that being receptor specific.
Ligand-activated NRs bind to hormone response elements embedded within chromatin and recruit various chromatin-modifying machines - including SWI/SNF, HATs and HMTs - which remodel chromatin to initiate transcription (Fig. 2). There is evidence supporting a distinct requirement for the ubiquitin enzymes and the $26 \mathrm{~S}$ proteasome in NR-mediated transcriptional regulation at least via the traditional role in proteolysis of NR and NR co-factor complexes. However, more studies are required to elucidate exactly how ubiquitin-proteasome components function in each step of the NR-mediated transcription process, particularly the elongation step where specific chromatin modifications are associated with gene activity (Fig. 2).

In summary, regulation of NR-mediated gene transcription by the ubiquitin-proteasome system is complex and may include multiple levels of control involving chromatin modification(s) and the possibility of dynamic interplay between histone modifications that facilitate binding of existing or novel chromatin modifying factors.

\section{Acknowledgements}

We thank Drs Derek Henley, Chris Brynczka, Pratibha Hebbar, Sayura Aoyagi and Fukuda Tomokazu for critical review of the manuscript.

\section{References}

Ahn SH, Kim M \& Buratowski S 2004 Phosphorylation of serine 2 within the RNA polymerase II C-terminal domain couples transcription and $3^{\prime}$ end processing. Molecular Cell 13 67-76.

Altincicek B, Tenbaum SP, Dressel U, Thormeyer D, Renkawitz R \& Baniahmad A 2000 Interaction of the corepressor Alien with DAX-1 is abrogated by mutations of DAX-1 involved in adrenal hypoplasia congenita. Fournal of Biological Chemistry 275 7662-7667.

Apcher GS, Heink S, Zantopf D, Kloetzel PM, Schmid HP, Mayer RJ \& Kruger E 2003 Human immunodeficiency virus-1 Tat protein interacts with distinct proteasomal alpha and beta subunits. FEBS Letters 553 200-204.

Aravind L \& Ponting CP 1998 Homologues of 26S proteasome subunits are regulators of transcription and translation. Protein Science 7 1250-1254.

Aravind L \& Koonin EV 2000 The U box is a modified RING finger - a common domain in ubiquitination. Current Biology 10 R132-134.

Archer TK \& Kinyamu HK 2004 Proteasome inhibition of glucocorticoid-mediated transcription: targeting elongation. Proceedings of the International 59th Harden/EMBO Conference, Meeting abstract P077, 28.

Baarends WM, Hoogerbrugge JW, Roest HP, Ooms M, Vreeburg J, Hoeijmakers JH \& Grootegoed JA 1999 Histone ubiquitination and chromatin remodeling in mouse spermatogenesis. Developmental Biology 207 322-333.

Banks GC, Deterding LJ, Tomer KB \& Archer TK 2001 Hormone-mediated dephosphorylation of specific histone $\mathrm{H} 1$ isoforms. Journal of Biological Chemistry 276 36467-36473. 
Barsoum J, Levinger L \& Varshavsky A 1982 On the chromatin structure of the amplified, transcriptionally active gene for dihydrofolate reductase in mouse cells. Fournal of Biological Chemistry $2575274-5282$.

Beaudenon SL, Huacani MR, Wang G, McDonnell DP \& Huibregtse JM 1999 Rsp5 ubiquitin-protein ligase mediates DNA damage-induced degradation of the large subunit of RNA polymerase II in Saccharomyces cerevisiae. Molecular and Cellular Biology 19 6972-6979.

Bech-Otschir D, Seeger M \& Dubiel W 2002 The COP9 signalosome: at the interface between signal transduction and ubiquitin-dependent proteolysis. Fournal of Cell Science $\mathbf{1 1 5}$ 467-473.

Bhattacharjee RN, Banks GC, Trotter KW, Lee HL \& Archer TK 2001 Histone $\mathrm{H} 1$ phosphorylation by Cdk2 selectively modulates mouse mammary tumor virus transcription through chromatin remodeling. Molecular and Cellular Biology 21 $5417-5425$

Blagosklonny MV 2001 Do VHL and HIF-1 mirror p53 and Mdm-2? Degradation-transactivation loops of oncoproteins and tumor suppressors. Oncogene 20 395-398.

Blanquart C, Mansouri R, Fruchart JC, Staels B \& Glineur C 2004 Different ways to regulate the PPARalpha stability. Biochemical and Biophysical Research Communications 319 663-670.

Bochtler M, Ditzel L, Groll M, Hartmann C \& Huber R 1999 The proteasome. Annual Review of Biophysics and Biomolecular Structure $\mathbf{2 8}$ 295-317.

Bregman DB, Halaban R, van Gool AJ, Henning KA, Friedberg EC \& Warren SL 1996 UV-induced ubiquitination of RNA polymerase II: a novel modification deficient in Cockayne syndrome cells. PNAS 93 11586-11590.

Bresnick EH, Bustin M, Marsaud V, Richard-Foy H \& Hager GL 1992 The transcriptionally-active MMTV promoter is depleted of histone H1. Nucleic Acids Research 20 273-278.

Briggs SD, Xiao T, Sun ZW, Caldwell JA, Shabanowitz J, Hunt DF, Allis CD \& Strahl BD 2002 Gene silencing: trans-histone regulatory pathway in chromatin. Nature $\mathbf{4 1 8} 498$.

Brzovic PS, Rajagopal P, Hoyt DW, King MC \& Klevit RE 2001 Structure of a BRCA1-BARD1 heterodimeric RING-RING complex. Nature Structural Biology 8 833-837.

Cardozo CP, Michaud C, Ost MC, Fliss AE, Yang E, Patterson C, Hall SJ \& Caplan AJ 2003 C-terminal Hsp-interacting protein slows androgen receptor synthesis and reduces its rate of degradation. Archives of Biochemistry and Biophysics 410 134-140.

Carrabino S, Carminati E, Talarico D, Pardi R \& Bianchi E 2004 Expression pattern of the JAB1/CSN5 gene during murine embryogenesis: colocalization with NEDD8. Gene Expression Patterns 4 423-431.

Chamovitz DA \& Segal D 2001 JAB1/CSN5 and the COP9 signalosome. A complex situation. EMBO Reports 2 96-101.

Chang C, Gonzalez F, Rothermel B, Sun L, Johnston SA \& Kodadek T 2001 The Gal4 activation domain binds Sug2 protein, a proteasome component, in vivo and in vitro. Fournal of Biological Chemistry 276 30956-30963.

Chauchereau A, Georgiakaki M, Perrin-Wolff M, Milgrom E \& Loosfelt H $2000 \mathrm{JAB} 1$ interacts with both the progesterone receptor and SRC-1. Fournal of Biological Chemistry $\mathbf{2 7 5}$ 8540-8548.

Chen HY, Sun JM, Zhang Y, Davie JR \& Meistrich ML 1998 Ubiquitination of histone $\mathrm{H} 3$ in elongating spermatids of rat testes. Fournal of Biological Chemistry 273 13165-13169.

Chiba T \& Tanaka K 2004 Cullin-based ubiquitin ligase and its control by NEDD8-conjugating system. Current Protein and Peptide Science 5 177-184.

Ciechanover A \& Schwartz AL 1998 The ubiquitin-proteasome pathway: the complexity and myriad functions of proteins death. PNAS 95 2727-2730.
Ciechanover A \& Brundin P 2003 The ubiquitin proteasome system in neurodegenerative diseases: sometimes the chicken, sometimes the egg. Neuron $\mathbf{4 0} 427-446$.

Ciechanover A, Orian A \& Schwartz AL 2000 Ubiquitin-mediated proteolysis: biological regulation via destruction. Bioessays 22 $442-451$.

Collingwood TN, Urnov FD \& Wolffe AP 1999 Nuclear receptors: coactivators, corepressors and chromatin remodeling in the control of transcription. Fournal of Molecular Endocrinology 23 255-275.

Conaway JW, Shilatifard A, Dvir A \& Conaway RC 2000 Control of elongation by RNA polymerase II. Trends in Biochemical Sciences 25 375-380.

Connell P, Ballinger CA, Jiang J, Wu Y, Thompson LJ, Hohfeld J \& Patterson C 2001 The co-chaperone CHIP regulates protein triage decisions mediated by heat-shock proteins. Nature Cell Biology 3 93-96.

Corey LL, Weirich CS, Benjamin IJ \& Kingston RE 2003 Localized recruitment of a chromatin-remodeling activity by an activator in vivo drives transcriptional elongation. Genes and Development 17 $1392-1401$.

Deng XW, Dubiel W, Wei N, Hofmann K, Mundt K, Colicelli J, Kato J, Naumann M, Segal D, Seeger M et al. 2000 Unified nomenclature for the COP9 signalosome and its subunits: an essential regulator of development. Trends in Genetics $\mathbf{1 6}$ 202-203.

Dennis AP, Haq RU \& Nawaz Z 2001 Importance of the regulation of nuclear receptor degradation. Frontiers in Bioscience 6 D954-959.

Deroo BJ \& Archer TK 2001 Glucocorticoid receptor-mediated chromatin remodeling in vivo. Oncogene 20 3039-3046.

Deroo BJ, Rentsch C, Sampath S, Young J, DeFranco DB \& Archer TK 2002 Proteasomal inhibition enhances glucocorticoid receptor transactivation and alters its subnuclear trafficking. Molecular and Cellular Biology 22 4113-4123.

Dover J, Schneider J, Tawiah-Boateng MA, Wood A, Dean K, Johnston M \& Shilatifard A 2002 Methylation of histone H3 by COMPASS requires ubiquitination of histone H2B by Rad6. Fournal of Biological Chemistry 277 28368-28371.

Dressel U, Thormeyer D, Altincicek B, Paululat A, Eggert M, Schneider S, Tenbaum SP, Renkawitz R \& Baniahmad A 1999 Alien, a highly conserved protein with characteristics of a corepressor for members of the nuclear hormone receptor superfamily. Molecular and Cellular Biology 19 3383-3394.

Dubiel W, Ferrell K, Dumdey R, Standera S, Prehn S \& Rechsteiner M 1995 Molecular cloning and expression of subunit 12: a non-MCP and non-ATPase subunit of the 26S protease. FEBS Letters 363 97-100.

Evans R \& O'Malley B 2004 www.nursa.org. The Nuclear Receptor Signaling Atlas.

Ezhkova E \& Tansey WP 2004 Proteasomal ATPases link ubiquitylation of histone $\mathrm{H} 2 \mathrm{~B}$ to methylation of histone $\mathrm{H} 3$. Molecular Cell 13 435-442.

Fan M, Bigsby RM \& Nephew KP 2003 The NEDD8 pathway is required for proteasome-mediated degradation of human estrogen receptor (ER)-alpha and essential for the antiproliferative activity of ICI 182,780 in ERalpha-positive breast cancer cells. Molecular Endocrinology 17 356-365.

Fan S, Wang J, Yuan R, Ma Y, Meng Q, Erdos MR, Pestell RG, Yuan F, Auborn KJ, Goldberg ID et al. 1999 BRCAl inhibition of estrogen receptor signaling in transfected cells. Science $\mathbf{2 8 4}$ 1354-1356.

Fan Y \& Skoultchi AI 2003 Genetic analysis of H1 linker histone subtypes and their functions in mice. Methods in Enzymology $\mathbf{3 7 7}$ 85-107.

Fang S, Jensen JP, Ludwig RL, Vousden KH \& Weissman AM $2000 \mathrm{Mdm} 2$ is a RING finger-dependent ubiquitin protein ligase for itself and p53. Fournal of Biological Chemistry $\mathbf{2 7 5}$ 8945-8951. 
Ferdous A, Gonzalez F, Sun L, Kodadek T \& Johnston SA 2001 The 19S regulatory particle of the proteasome is required for efficient transcription elongation by RNA polymerase II. Molecular Cell 7 981-991.

Ferdous A, Kodadek T \& Johnston SA 2002 A nonproteolytic function of the $19 \mathrm{~S}$ regulatory subunit of the $26 \mathrm{~S}$ proteasome is required for efficient activated transcription by human RNA polymerase II. Biochemistry 41 12798-12805.

Finley D, Tanaka K, Mann C, Feldmann H, Hochstrasser M, Vierstra R, Johnston S, Hampton R, Haber J, McCusker J et al. 1998 Unified nomenclature for subunits of the Saccharomyces cerevisiae proteasome regulatory particle. Trends in Biochemical Sciences $23244-245$.

Fischle W, Wang Y \& Allis CD 2003a Binary switches and modification cassettes in histone biology and beyond. Nature $\mathbf{4 2 5}$ 475-479.

Fischle W, Wang Y \& Allis CD 2003b Histone and chromatin cross-talk. Current Opinion in Cell Biology 15 172-183.

Fletcher TM, Xiao N, Mautino G, Baumann CT, Wolford R, Warren BS \& Hager GL 2002 ATP-dependent mobilization of the glucocorticoid receptor during chromatin remodeling. Molecular and Cellular Biology 22 3255-3263.

Fraser RA, Rossignol M, Heard DJ, Egly JM \& Chambon P 1997 SUG1, a putative transcriptional mediator and subunit of the PA700 proteasome regulatory complex, is a DNA helicase. Fournal of Biological Chemistry $2727122-7126$.

Frasor J, Stossi F, Danes JM, Komm B, Lyttle CR \& Katzenellenbogen BS 2004 Selective estrogen receptor modulators: discrimination of agonistic versus antagonistic activities by gene expression profiling in breast cancer cells. Cancer Research 64 1522-1533.

Fryer CJ \& Archer TK 1998 Chromatin remodelling by the glucocorticoid receptor requires the BRG1 complex. Nature 393 88-91.

Georgel PT, Fletcher TM, Hager GL \& Hansen JC 2003 Formation of higher-order secondary and tertiary chromatin structures by genomic mouse mammary tumor virus promoters. Genes and Development 17 1617-1629.

Gerber M \& Shilatifard A 2003 Transcriptional elongation by RNA polymerase II and histone methylation. Fournal of Biological Chemistry 278 26303-26306.

Gianni M, Bauer A, Garattini E, Chambon P \& Rochette-Egly C 2002 Phosphorylation by p38 MAPK and recruitment of SUG-1 are required for RA-induced RAR gamma degradation and transactivation. EMBO Journal 21 3760-3769.

Gillette TG, Gonzalez F, Delahodde A, Johnston SA \& Kodadek T 2004 Physical and functional association of RNA polymerase II and the proteasome. PNAS $1015904-5909$.

Glickman MH \& Ciechanover A 2002 The ubiquitin-proteasome proteolytic pathway: destruction for the sake of construction. Physiological Reviews 82 373-428.

Glickman MH, Rubin DM, Coux O, Wefes I, Pfeifer G, Gjeka Z, Baumeister W, Fried VA \& Finley D 1998 A subcomplex of the proteasome regulatory particle required for ubiquitin-conjugate degradation and related to the COP9-signalosome and eIF3. Cell 94 615-623.

Goldberg AL, Elledge SJ \& Harper JW 2001 The cellular chamber of doom. Scientific American 284 68-73.

Goldknopf IL, Taylor CW, Baum RM, Yeoman LC, Olson MO, Prestayko AW \& Busch H 1975 Isolation and characterization of protein A24, a 'histone-like' non-histone chromosomal protein. Fournal of Biological Chemistry $2507182-7187$.

Gonzalez F, Delahodde A, Kodadek T \& Johnston SA 2002 Recruitment of a $19 \mathrm{~S}$ proteasome subcomplex to an activated promoter. Science 296 548-550.

Grossman SR, Deato ME, Brignone C, Chan HM, Kung AL, Tagami H, Nakatani Y \& Livingston DM 2003 Polyubiquitination of p53 by a ubiquitin ligase activity of p300. Science $\mathbf{3 0 0}$ 342-344.

Haas AL, Reback PB \& Chau V 1991 Ubiquitin conjugation by the yeast RAD6 and CDC34 gene products. Comparison to their putative rabbit homologs, E2(20K) AND E2(32K). Fournal of Biological Chemistry 266 5104-5112.

Hager GL, Nagaich AK, Johnson TA, Walker DA \& John S 2004 Dynamics of nuclear receptor movement and transcription. Biochimica et Biophysica Acta $\mathbf{1 6 7 7} 46-51$.

Hampsey M \& Reinberg D 2003 Tails of intrigue: phosphorylation of RNA polymerase II mediates histone methylation. Cell $\mathbf{1 1 3}$ 429-432.

Harari-Steinberg O \& Chamovitz DA 2004 The COP9 signalosome: mediating between kinase signaling and protein degradation. Current Protein and Peptide Science 5 185-189.

Hebbar PB \& Archer TK 2003 Chromatin remodeling by nuclear receptors. Chromosoma 111 495-504.

Henry KW, Wyce A, Lo WS, Duggan LJ, Emre NC, Kao CF, Pillus L, Shilatifard A, Osley MA \& Berger SL 2003 Transcriptional activation via sequential histone $\mathrm{H} 2 \mathrm{~B}$ ubiquitylation and deubiquitylation, mediated by SAGA-associated Ubp8. Genes and Development 17 2648-2663.

Hoang T, Fenne IS, Cook C, Borud B, Bakke M, Lien EA \& Mellgren G 2004 cAMP-dependent protein kinase regulates ubiquitin-proteasome mediated degradation and subcellular localization of the nuclear receptor coactivator GRIP1. Fournal of Biological Chemistry 279 49120-49130.

Hook SS, Orian A, Cowley SM \& Eisenman RN 2002 Histone deacetylase 6 binds polyubiquitin through its zinc finger (PAZ domain) and copurifies with deubiquitinating enzymes. PNAS 99 13425-13430.

Hsiao PW, Deroo BJ \& Archer TK 2002 Chromatin remodeling and tissue-selective responses of nuclear hormone receptors. Biochemistry and Cell Biology 80 343-351.

Huibregtse JM, Yang JC \& Beaudenon SL 1997 The large subunit of RNA polymerase II is a substrate of the Rsp5 ubiquitin-protein ligase. PNAS 94 3656-3661.

Hwang WW, Venkatasubrahmanyam S, Ianculescu AG, Tong A, Boone C \& Madhani HD 2003 A conserved RING finger protein required for histone $\mathrm{H} 2 \mathrm{~B}$ monoubiquitination and cell size control. Molecular Cell 11 261-266.

Imhof MO \& McDonnell DP 1996 Yeast RSP5 and its human homolog hRPF1 potentiate hormone-dependent activation of transcription by human progesterone and glucocorticoid receptors. Molecular and Cellular Biology 16 2594-2605.

Ishizuka T, Satoh T, Monden T, Shibusawa N, Hoshida T, Yamada M \& Movi M 2001 Human immunodeficiency virus type I Tat binding protein-1 is a transcriptional coactivator specific for TR Molecular Endocrinology 15 1329-1343.

Ismaili N \& Garabedian MJ 2004 Modulation of glucocorticoid receptor function via phosphorylation. Annals of the New York Academy of Sciences $\mathbf{1 0 2 4} 86-101$.

Jackson PK, Eldridge AG, Freed E, Furstenthal L, Hsu JY, Kaiser BK \& Reimann JD 2000 The lore of the RINGs: substrate recognition and catalysis by ubiquitin ligases. Trends in Cell Biology $10429-439$.

Jason LJ, Moore SC, Lewis JD, Lindsey G \& Ausio J 2002 Histone ubiquitination: a tagging tail unfolds? Bioessays 24 166-174.

Joazeiro CA \& Weissman AM 2000 RING finger proteins: mediators of ubiquitin ligase activity. Cell $\mathbf{1 0 2} 549-552$.

Kang Z, Pirskanen A, Janne OA \& Palvimo JJ 2002 Involvement of proteasome in the dynamic assembly of the androgen receptor transcription complex. Fournal of Biological Chemistry $\mathbf{2 7 7}$ 48366-48371.

Kawaguchi Y, Kovacs JJ, McLaurin A, Vance JM, Ito A \& Yao TP 2003 The deacetylase HDAC6 regulates aggresome formation and cell viability in response to misfolded protein stress. Cell $\mathbf{1 1 5}$ $727-738$. 
Kim J, Jia L, Tilley WD \& Coetzee GA 2003 Dynamic methylation of histone $\mathrm{H} 3$ at lysine 4 in transcriptional regulation by the androgen receptor. Nucleic Acids Research 31 6741-6747.

Kinyamu HK \& Archer TK 2003 Estrogen receptor-dependent proteasomal degradation of the glucocorticoid receptor is coupled to an increase in mdm2 protein expression. Molecular and Cellular Biology 23 5867-5881.

Kinyamu HK \& Archer TK 2004 Modifying chromatin to permit steroid hormone receptor-dependent transcription. Biochimica et Biophysica Acta 1677 30-45.

Kisselev AF \& Goldberg AL 2001 Proteasome inhibitors: from research tools to drug candidates. Chemistry and Biology $\mathbf{8}$ 739-758.

Kitagawa H, Fujiki R, Yoshimura K, Mezaki Y, Uematsu Y, Matsui D, Ogawa S, Unno K, Okubo M, Tokita A et al. 2003 The chromatin-remodeling complex WINAC targets a nuclear receptor to promoters and is impaired in Williams syndrome. Cell $\mathbf{1 1 3}$ 905-917.

Komarnitsky P, Cho EJ \& Buratowski S 2000 Different phosphorylated forms of RNA polymerase II and associated mRNA processing factors during transcription. Genes and Development 14 2452-2460.

Kopf E, Plassat JL, Vivat V, de The H, Chambon P \& Rochette-Egly C 2000 Dimerization with retinoid X receptors and phosphorylation modulate the retinoic acid-induced degradation of retinoic acid receptors alpha and gamma through the ubiquitin-proteasome pathway. Fournal of Biological Chemistry 275 33280-33288.

Kouzarides T 2002 Histone methylation in transcriptional control. Current Opinion in Genetics and Development 12 198-209.

Krogan NJ, Dover J, Wood A, Schneider J, Heidt J, Boateng MA, Dean K, Ryan OW, Golshani A, Johnston M et al. 2003 The $\mathrm{Pafl}$ complex is required for histone $\mathrm{H} 3$ methylation by COMPASS and Dotlp: linking transcriptional elongation to histone methylation. Molecular Cell 11 721-729.

Lange CA, Shen T \& Horwitz KB 2000 Phosphorylation of human progesterone receptors at serine-294 by mitogen-activated protein kinase signals: their degradation by the $26 \mathrm{~S}$ proteasome. PNAS 97 1032-1037.

Lee HL \& Archer TK 1998 Prolonged glucocorticoid exposure dephosphorylates histone $\mathrm{H} 1$ and inactivates the MMTV promoter. EMBO Fournal 17 1454-1466.

Lee JW, Ryan F, Swaffield JC, Johnston SA \& Moore DD 1995 Interaction of thyroid-hormone receptor with a conserved transcriptional mediator. Nature 374 91-94.

LeRoy G, Loyola A, Lane WS \& Reinberg D 2000 Purification and characterization of a human factor that assembles and remodels chromatin. Foumal of Biological Chemistry 275 14787-14790.

Levinger L \& Varshavsky A 1982 Selective arrangement of ubiquitinated and $\mathrm{D} 1$ protein-containing nucleosomes within the Drosophila genome. Cell 28 375-385.

Li J, Lin Q, Yoon HG, Huang ZQ, Strahl BD, Allis CD \& Wong J 2002 Involvement of histone methylation and phosphorylation in regulation of transcription by thyroid hormone receptor. Molecular and Cellular Biology 22 5688-5697.

Li X, Wong J, Tsai SY, Tsai MJ \& O’Malley BW 2003 Progesterone and glucocorticoid receptors recruit distinct coactivator complexes and promote distinct patterns of local chromatin modification. Molecular and Cellular Biology 23 3763-3773.

Liang G, Lin JC, Wei V, Yoo C, Cheng JC, Nguyen CT, Weisenberger DJ, Egger G, Takai D, Gonzales FA et al. 2004 Distinct localization of histone $\mathrm{H} 3$ acetylation and H3-K4 methylation to the transcription start sites in the human genome. PNAS $1017357-7362$.

Lin HK, Wang L, Hu YC, Altuwaijri S \& Chang C 2002 Phosphorylation-dependent ubiquitylation and degradation of androgen receptor by Akt require Mdm2 E3 ligase. EMBO Fournal 21 4037-4048.

Lin Q Inselman A, Han X, Xu H, Zhang W, Handel MA \& Skoultchi AI 2004 Reductions in linker histone levels are tolerated in developing spermatocytes but cause changes in specific gene expression. Fournal of Biological Chemistry 279 23525-23535.

Lipford JR \& Deshaies RJ 2003 Diverse roles for ubiquitindependent proteolysis in transcriptional activation. Nature Cell Biology 5 845-850.

Lonard DM, Nawaz Z, Smith CL \& O'Malley BW 2000 The 26S proteasome is required for estrogen receptor-alpha and coactivator turnover and for efficient estrogen receptor-alpha transactivation. Molecular Cell 5 939-948.

Lonard DM, Tsai SY \& O’Malley BW 2004 Selective estrogen receptor modulators 4-hydroxytamoxifen and raloxifene impact the stability and function of SRC-1 and SRC-3 coactivator proteins. Molecular and Cellular Biology 24 14-24.

Luger K, Rechsteiner TJ, Flaus AJ, Waye MM \& Richmond TJ 1997 Characterization of nucleosome core particles containing histone proteins made in bacteria. Fournal of Molecular Biology 272 301-311.

Ma H, Baumann CT, Li H, Strahl BD, Rice R, Jelinek MA, Aswad DW, Allis CD, Hager GL \& Stallcup MR 2001 Hormonedependent, CARM1-directed, arginine-specific methylation of histone H3 on a steroid-regulated promoter. Current Biology 11 1981-1985.

McKenna NJ \& O'Malley BW 2002 Combinatorial control of gene expression by nuclear receptors and coregulators. Cell $\mathbf{1 0 8}$ 465-474.

Maglich JM, Sluder A, Guan X, Shi Y, McKee DD, Carrick K, Kamdar K, Willson TM \& Moore JT 2001 Comparison of complete nuclear receptor sets from the human, Caenorhabditis elegans and Drosophila genomes. Genome Biology 2 RESEARCH0029.

Mangelsdorf DJ, Thummel C, Beato M, Herrlich P, Schutz G, Umesono K, Blumberg B, Kastner P, Mark M, Chambon P et al. 1995 The nuclear receptor superfamily: the second decade. Cell 83 835-839.

Mason PB \& Struhl K 2003 The FACT complex travels with elongating RNA polymerase II and is important for the fidelity of transcriptional initiation in vivo. Molecular and Cellular Biology 23 8323-8333.

Masuyama H \& Hiramatsu Y 2003 Involvement of suppressor for Gal-1 in the ubiquitin/proteasome-mediated degradation of estrogen receptors. Fournal of Biological Chemistry.

Meek DW 1999 Mechanisms of switching on p53: a role for covalent modification? Oncogene 18 7666-7675.

Metivier R, Penot G, Hubner MR, Reid G, Brand H, Kos M \& Gannon F 2003 Estrogen receptor-alpha directs ordered, cyclical, and combinatorial recruitment of cofactors on a natural target promoter. Cell 115 751-763.

Minsky N \& Oren M 2003 Mdm2 is a E3 ubiquitin-ligase for histone H2B. Second International Mdm2 Workshop, Meeting abstract 54 .

Mitsui A \& Sharp PA 1999 Ubiquitination of RNA polymerase II large subunit signaled by phosphorylation of carboxyl-terminal domain. PNAS $966054-6059$.

Molinari E, Gilman M \& Natesan S 1999 Proteasome-mediated degradation of transcriptional activators correlates with activation domain potency in vivo. EMBO fournal 18 6439-6447.

Morillon A, Karabetsou N, O’Sullivan J, Kent N, Proudfoot N \& Mellor J 2003 Isw 1 chromatin remodeling ATPase coordinates transcription elongation and termination by RNA polymerase II. Cell 115 425-435.

Muller WG, Walker D, Hager GL \& McNally JG 2001 Large-scale chromatin decondensation and recondensation regulated by transcription from a natural promoter. Fournal of Cell Biology 154 33-48. 
Muratani M \& Tansey WP 2003 How the ubiquitin-proteasome system controls transcription. Nature Reviews. Molecular Cell Biology 4 192-201.

Narlikar GJ, Fan HY \& Kingston RE 2002 Cooperation between complexes that regulate chromatin structure and transcription. Cell $108475-487$.

Nathan D, Sterner DE \& Berger SL 2003 Histone modifications: now summoning sumoylation. PNAS 100 13118-13120.

Nawaz Z \& O'Malley BW 2004 Urban renewal in the nucleus: is protein turnover by proteasomes absolutely required for nuclear receptor-regulated transcription? Molecular Endocrinology 18 493-499.

Nawaz Z, Lonard DM, Dennis AP, Smith CL \& O’Malley BW 1999 Proteasome-dependent degradation of the human estrogen receptor. PNAS 96 1858-1862.

Nelbock P, Dillon PJ, Perkins A \& Rosen CA 1990 A cDNA for a protein that interacts with the human immunodeficiency virus Tat transactivator. Science 248 1650-1653.

Ng HH, Dole S \& Struhl K 2003 The Rtfl component of the Pafl transcriptional elongation complex is required for ubiquitination of histone H2B. Fournal of Biological Chemistry 278 33625-33628.

Ohta T \& Fukuda M 2004 Ubiquitin and breast cancer. Oncogene 23 2079-2088.

Orphanides G, Wu WH, Lane WS, Hampsey M \& Reinberg D 1999 The chromatin-specific transcription elongation factor FACT comprises human SPT16 and SSRP1 proteins. Nature 400 $284-288$.

Osley MA 2004 H2B ubiquitylation: the end is in sight. Biochimica et Biophysica Acta 1677 74-78.

Park JJ, Irvine RA, Buchanan G, Koh SS, Park JM, Tilley WD, Stallcup MR, Press MF \& Coetzee GA 2000 Breast cancer susceptibility gene 1 (BRCAI) is a coactivator of the androgen receptor. Cancer Research 60 5946-5949.

Patterson C 2002 A new gun in town: the $\mathrm{U}$ box is a ubiquitin ligase domain. Science's STKE: Signal Transduction Knowledge Environment 2002 PE4.

Perissi V, Aggarwal A, Glass CK, Rose DW \& Rosenfeld MG 2004 A corepressor/coactivator exchange complex required for transcriptional activation by nuclear receptors and other regulated transcription factors. Cell 116 511-526.

Peters JM 1998 SCF and APC: the Yin and Yang of cell cycle regulated proteolysis. Current Opinion in Cell Biology 10 759-768.

Pham AD \& Sauer F 2000 Ubiquitin-activating/conjugating activity of TAFII250, a mediator of activation of gene expression in Drosophila. Science 289 2357-2360.

Pickart CM 2004 Back to the future with ubiquitin. Cell 116 181-190.

Poukka H, Aarnisalo P, Karvonen U, Palvimo JJ \& Janne OA 1999 Ubc9 interacts with the androgen receptor and activates receptor-dependent transcription. Fournal of Biological Chemistry 274 19441-19446.

Poukka H, Karvonen U, Janne OA \& Palvimo JJ 2000 Covalent modification of the androgen receptor by small ubiquitin-like modifier 1 (SUMO-1). PNAS 97 14145-14150.

Privalsky ML 2004 The role of corepressors in transcriptional regulation by nuclear hormone receptors. Annual Review of Physiology 66 315-360.

Rechsteiner M, Realini C \& Ustrell V 2000 The proteasome activator 11 S REG (PA28) and class I antigen presentation. Biochemical fournal 345 1-15.

Reid G, Hubner MR, Metivier R, Brand H, Denger S, Manu D, Beaudouin J, Ellenberg J \& Gannon F 2003 Cyclic, proteasome-mediated turnover of unliganded and liganded ERalpha on responsive promoters is an integral feature of estrogen signaling. Molecular Cell 11 695-707.

Robinson-Rechavi M, Carpentier AS, Duffraisse M \& Laudet V 2001 How many nuclear hormone receptors are there in the human genome? Trends in Genetics 17 554-556.
Roeder RG 1996 The role of general initiation factors in transcription by RNA polymerase II. Trends in Biochemical Sciences 21 327-335.

Roest HP, van Klaveren J, de Wit J, van Gurp CG, Koken MH, Vermey M, van Roijen JH, Hoogerbrugge JW, Vreeburg JT, Baarends WM et al. 1996 Inactivation of the HR6B ubiquitin-conjugating DNA repair enzyme in mice causes male sterility associated with chromatin modification. Cell $\mathbf{8 6}$ 799-810.

Roest HP, Baarends WM, de Wit J, van Klaveren JW, Wassenaar E, Hoogerbrugge JW, van Cappellen WA, Hoeijmakers JH \& Grootegoed JA 2004 The ubiquitin-conjugating DNA repair enzyme HR6A is a maternal factor essential for early embryonic development in mice. Molecular and Cellular Biology 24 5485-5495.

Saji S, Okumura N, Eguchi H, Nakashima S, Suzuki A, Toi M, Nozawa Y \& Hayashi S 2001 MDM2 enhances the function of estrogen receptor alpha in human breast cancer cells. Biochemical and Biophysical Research Communications 281 259-265.

Salghetti SE, Muratani M, Wijnen H, Futcher B \& Tansey WP 2000 Functional overlap of sequences that activate transcription and signal ubiquitin-mediated proteolysis. PNAS 97 3118-3123.

Salghetti SE, Caudy AA, Chenoweth JG \& Tansey WP 2001 Regulation of transcriptional activation domain function by ubiquitin. Science 293 1651-1653.

Salvat C, Aquaviva C, Jariel-Encontre I, Ferrara P, Pariat M, Steff AM, Carillo S \& Piechaczyk M 1999 Are there multiple proteolytic pathways contributing to c-Fos, c-Jun and p53 protein degradation in vivo? Molecular Biology Reports 26 45-51.

Santos-Rosa H, Schneider R, Bernstein BE, Karabetsou N, Morillon A, Weise C, Schreiber SL, Mellor J \& Kouzarides T 2003 Methylation of histone H3 K4 mediates association of the Iswlp ATPase with chromatin. Molecular Cell 12 1325-1332.

Saunders A, Werner J, Andrulis ED, Nakayama T, Hirose S, Reinberg D \& Lis JT 2003 Tracking FACT and the RNA polymerase II elongation complex through chromatin in vivo. Science 301 1094-1096.

Schaaf MJ \& Cidlowski JA 2003 Molecular determinants of glucocorticoid receptor mobility in living cells: the importance of ligand affinity. Molecular and Cellular Biology 23 1922-1934.

Scheffner M 1998 Ubiquitin, E6-AP, and their role in p53 inactivation. Pharmacology and Therapeutics 78 129-139.

Schneider R, Bannister AJ, Myers FA, Thorne AW, Crane-Robinson C \& Kouzarides T 2004 Histone H3 lysine 4 methylation patterns in higher eukaryotic genes. Nature Cell Biology 6 73-77.

Schwartz AL \& Ciechanover A 1999 The ubiquitin-proteasome pathway and pathogenesis of human diseases. Annual Review of Medicine 50 57-74.

Schwechheimer C \& Deng XW 2001 COP9 signalosome revisited: a novel mediator of protein degradation. Trends in Cell Biology 11 420-426.

Sedkov Y, Cho E, Petruk S, Cherbas L, Smith ST, Jones RS, Cherbas P, Canaani E, Jaynes JB \& Mazo A 2003 Methylation at lysine 4 of histone $\mathrm{H} 3$ in ecdysone-dependent development of Drosophila. Nature 426 78-83.

Sengupta S \& Wasylyk B 2001 Ligand-dependent interaction of the glucocorticoid receptor with p53 enhances their degradation by Hdm2. Genes and Development 15 2367-2380.

Shang Y, Hu X, DiRenzo J, Lazar MA \& Brown M 2000 Cofactor dynamics and sufficiency in estrogen receptor-regulated transcription. Cell 103 843-852.

Shao W, Keeton EK, McDonnell DP \& Brown M 2004 Coactivator AIB 1 links estrogen receptor transcriptional activity and stability. PNAS 101 11599-11604.

Shen T, Horwitz KB \& Lange CA 2001 Transcriptional hyperactivity of human progesterone receptors is coupled to their ligand-dependent down-regulation by mitogen-activated protein kinase-dependent phosphorylation of serine 294. Molecular and Cellular Biology 21 6122-6131. 
Shilatifard A, Conaway RC \& Conaway JW 2003 The RNA polymerase II elongation complex. Annual Review of Biochemistry 72 693-715.

Smith CL, DeVera DG, Lamb DJ, Nawaz Z, Jiang YH, Beaudet AL \& O'Malley BW 2002 Genetic ablation of the steroid receptor coactivator-ubiquitin ligase, E6-AP, results in tissue-selective steroid hormone resistance and defects in reproduction. Molecular and Cellular Biology 22 525-535.

Stallcup MR, Kim JH, Teyssier C, Lee YH, Ma H \& Chen D 2003 The roles of protein-protein interactions and protein methylation in transcriptional activation by nuclear receptors and their coactivators. Fournal of Steroid Biochemistry and Molecular Biology 85 $139-145$.

Stavreva DA, Muller WG, Hager GL, Smith CL \& McNally JG 2004 Rapid glucocorticoid receptor exchange at a promoter is coupled to transcription and regulated by chaperones and proteasomes. Molecular and Cellular Biology 24 2682-2697.

Stenoien DL, Patel K, Mancini MG, Dutertre M, Smith CL, O'Malley BW \& Mancini MA 2001 FRAP reveals that mobility of oestrogen receptor-alpha is ligand- and proteasome-dependent. Nature Cell Biology 3 15-23.

Stoner M, Saville B, Wormke M, Dean D, Burghardt R \& Safe S 2002 Hypoxia induces proteasome-dependent degradation of estrogen receptor alpha in ZR-75 breast cancer cells. Molecular Endocrinology 16 2231-2242.

Sun L, Johnston SA \& Kodadek T 2002 Physical association of the APIS complex and general transcription factors. Biochemical and Biophysical Research Communications 296 991-999.

Sun ZW \& Allis CD 2002 Ubiquitination of histone H2B regulates H3 methylation and gene silencing in yeast. Nature 418 104-108.

Swaffield JC, Melcher K \& Johnston SA 1995 A highly conserved ATPase protein as a mediator between acidic activation domains and the TATA-binding protein. Nature 374 88-91.

Thorne AW, Sautiere P, Briand G \& Crane-Robinson C 1987 The structure of ubiquitinated histone H2B. EMBO Fournal 6 1005-1010.

Turner SD, Ricci AR, Petropoulos H, Genereaux J, Skerjanc IS \& Brandl CJ 2002 The E2 ubiquitin conjugase Rad6 is required for the ArgR/Mcml repression of ARG1 transcription. Molecular and Cellular Biology 22 4011-4019.

Tyers M \& Jorgensen P 2000 Proteolysis and the cell cycle: with this RING I do thee destroy. Current Opinion in Genetics and Development 10 54-64.

Ulrich HD 2002 Degradation or maintenance: actions of the ubiquitin system on eukaryotic chromatin. Eukaryotic Cell $\mathbf{1}$ $1-10$.

Voges D, Zwickl P \& Baumeister W 1999 The 26S proteasome: a molecular machine designed for controlled proteolysis. Annual Review of Biochemistry 68 1015-1068.

von Arnim AG 2003 On again-off again: COP9 signalosome turns the key on protein degradation. Current Opinion in Plant Biology 6 $520-529$.

Wallace AD \& Cidlowski JA 2001 Proteasome-mediated glucocorticoid receptor degradation restricts transcriptional signaling by glucocorticoids. Fournal of Biological Chemistry 276 $42714-42721$.

Webster JC, Jewell CM, Bodwell JE, Munck A, Sar M \& Cidlowski JA 1997 Mouse glucocorticoid receptor phosphorylation status influences multiple functions of the receptor protein. Fournal of Biological Chemistry 272 9287-9293.

Weeda G, Rossignol M, Fraser RA, Winkler GS, Vermeulen W, van 't Veer LJ, Ma L, Hoeijmakers JH \& Egly JM 1997 The XPB subunit of repair/transcription factor TFIIH directly interacts with SUG1, a subunit of the $26 \mathrm{~S}$ proteasome and putative transcription factor. Nucleic Acids Research $\mathbf{2 5}$ $2274-2283$.

Wei N \& Deng XW 2003 The COP9 signalosome. Annual Review of Cell and Developmental Biology 19 261-286.

Wei N, Chamovitz DA \& Deng XW 1994 Arabidopsis COP9 is a component of a novel signaling complex mediating light control of development. Cell 78 117-124.

Wijayaratne AL \& McDonnell DP 2001 The human estrogen receptor alpha is a ubiquitinated protein whose stability is affected differentially by agonists, antagonists, and selective estrogen receptor modulators. Fournal of Biological Chemistry 276 35684-35692.

Wolffe AP \& Hayes JJ 1999 Chromatin disruption and modification. Nucleic Acids Research 27 711-720.

Wong BR, Parlati F, Qu K, Demo S, Pray T, Huang J, Payan DG \& Bennett MK 2003 Drug discovery in the ubiquitin regulatory pathway. Drug Discovery Today 8 746-754.

Wood A, Krogan NJ, Dover J, Schneider J, Heidt J, Boateng MA, Dean K, Golshani A, Zhang Y, Greenblatt JF et al. 2003 Brel, an E3 ubiquitin ligase required for recruitment and substrate selection of Rad6 at a promoter. Molecular Cell 11 267-274.

Wormke M, Stoner M, Saville B, Walker K, Abdelrahim M, Burghardt R \& Safe S 2003 The aryl hydrocarbon receptor mediates degradation of estrogen receptor alpha through activation of proteasomes. Molecular and Cellular Biology 23 $1843-1855$.

Xiao B, Wilson JR \& Gamblin SJ 2003 SET domains and histone methylation. Current Opinion in Structural Biology 13 699-705.

Yan F, Gao X, Lonard DM \& Nawaz Z 2003 Specific ubiquitin-conjugating enzymes promote degradation of specific nuclear receptor coactivators. Molecular Endocrinology 17 1315-1331.

Zhang X, Jeyakumar M, Petukhov S \& Bagchi MK 1998 A nuclear receptor corepressor modulates transcriptional activity of antagonist-occupied steroid hormone receptor. Molecular Endocrinology 12 513-524.

Zhang Y 2003 Transcriptional regulation by histone ubiquitination and deubiquitination. Genes and Development 17 2733-2740.

Received 29 October 2004 Accepted 16 November 2004 